\title{
Temporal dynamics of trust in ongoing inter-organizational relationships
}

\author{
Ahmet Ekici* \\ Bilkent University, Faculty of Business Administration, 06800 Bilkent, Ankara, Turkey
}

\section{A R T I C L E I N F O}

\section{Article history:}

Received 17 September 2011

Received in revised form 18 September 2012

Accepted 8 February 2013

Available online 26 March 2013

\section{Keywords:}

Trust

Betrayal

Dark sides

Inter-organizational relationship

Relationship dissolution

\begin{abstract}
A B S T R A C T
This paper reports the results of a qualitative study undertaken to understand the nature of trust and its consequences for both suppliers and buyers in short term (relatively new) and long term (older/more mature) relationships in inter-organizational contexts. Scholars have recently pointed out the importance of research that investigates the temporal characteristics and dynamics of trust in inter-organizational studies. Our paper responds to this call by indentifying the changing nature of the level of trust as the buyer-supplier relationship matures. Our findings contribute to sparse and conflicting previous research on the relationship between length of partnership and perceptions of trust, types of dark side consequences of trusting relationships, and reasons buyers and suppliers continue or terminate low/no-trust associations. Specifically, we illustrate that buyers and suppliers draw on substantially different metaphors for understanding the nature of trust in long and short term exchange relationships. Suppliers see marked differences in trust with long term versus short term exchange partners, while buyers see little or no difference. Suppliers and buyers also appear to have different conceptions of how trust is nested (or not) within the broader economic and/or personal relationship. Through our inductive model, we elaborate several types of betrayal and disappointment, distinguish several factors that lead suppliers and buyers to stay in relationships with partners they don't trust, and identify key issues that topple untrusting relationships into terminated relationships.
\end{abstract}

(c) 2013 Elsevier Inc. All rights reserved.

\section{Introduction}

One of the central issues in inter-organizational studies is understanding and managing relationships between firms. For example, the long tradition within marketing of studying inter-organizational relationships goes back to the foundations of the discipline (e.g. Alderson, 1958, 1965; McGary, 1952). After a couple of decades of neglect, scholars have regained their interest in the topic and focused on inter-organizational relations in such areas as industrial marketing (Hakansson, 1982; Hakansson \& Snehota, 1995), relationship marketing (e.g. Ganesan, 1994; Morgan \& Hunt, 1994; Sheth \& Parvatiyar, 1994), and marketing channels (e.g. Dwyer, Schurr, \& Oh, 1987). The majority of this research, both in marketing and business in general (e.g. Casson, 1990; Ghosal \& Bartlett, 1990), is interested in the role and significance of developing "trusting" relationships. In other words, trust has been identified as one of the central constructs in inter-organizational relationships (Smith \& Barclay, 1997).

Scholars in marketing, as well as in management, have paid increasing attention to various aspects of trust, including its conceptualization (e.g. Bromiley \& Cummings, 1995; Lewicki \& Bunker, 1995; Sitkin \& Roth, 1993); development (e.g. Blau, 1964; Rempel, Holmes, \& Zanna, 1985; Zand, 1972); different forms (Barber, 1983; Bowlby, 1982; McAllister, 1995; Shapiro, 1987; Thomas \& Skinner,

\footnotetext{
* Tel.: +90 312290 2628; fax: +90 3122664958.

E-mail address: ekici@bilkent.edu.tr.
}

2010; Wicks, Berman, \& Jones, 1999; Zucker, 1986); uses as a control mechanism (e.g. Argyris, 1952; Chiles \& McMackin, 1996; Huemer, Bostrom, \& Felzensztein, 2009; Oliver, 1990; Yang, Zhou, \& Jiang, 2011); consequences such as cooperation (Axelrod, 1984; Mayer, Davis, \& Schoorman, 1995; McAllister, 1995), confidence (Dasgupta, 1998; Das \& Teng, 1998), competitive advantage (Barney \& Hansen, 1994); antecedents such as culture (Cox, 1991; Doney, Cannon, \& Mullen, 1998; Lohtia, Bello, \& Porter, 2009; Nametz \& Christensen, 1996), trusting dispositions (McKnight, Cummings, \& Chervany, 1998; Rotter, 1967), satisfaction (e.g. Greenberg, 1997; Leonidou, Talias, \& Leonidou, 2008; Lewicki, 1983); and the violation and abuse of trust (e.g. Bies \& Tripp, 1996; Granovetter, 1985; Hogan \& Hogan, 1994; Wang \& Huff, 2007).

In spite of this high level of interest in the topic, there are still many areas of trust that are either unexplored or unresolved. As a recent review article published in Industrial Marketing and Management notes; "Despite the increased interest among the academics, the theory of trust is still developing" (Seppanen, Blomqvist, \& Sundqvist, 2007, p. 249). In addition to the growing number of journal articles, there have also been several special issues (e.g. Academy of Management ReviewAMR 1998; Organization Science 2001 and 2003; Journal of European Marketing-JEM 2007). As Rousseau, Sitkin, Burt, and Camerer (1998) indicated in the introduction of the AMR special issue, trust is an interdisciplinary and a very complex topic: "A phenomenon as complex as trust requires theory and research methodology that reflect trust's many facets and levels" (p. 393). In addition, the other special issues 
and influential review articles listed above have called for alternative methods to better understand the complex nature of the role of trust in inter-organizational contexts. For example, in his introduction of the JEM special issue, Arnott (2007) called for "interpretivist approaches to the study of trust, what is in essence, an immeasurable entity" (p. 986), and after analyzing about 15 years of empiricalquantitative studies on trust, Seppanen et al. (2007) pointed out the need for "qualitative empirical studies...for a concept that is apparently not easily quantifiable" (p. 261). Encouraged by these calls, in this paper, we review some of the recent works in business-to-business marketing, draw research questions from these studies, and through the use of interpretative research methodologies, provide some directions to the rather complex dynamics of inter-organizational relationships.

More specifically, we draw on semi-structured in-depth interviews with over 70 industrial buyers and suppliers from various industries on the topic of trust in exchange relationships. We intend to provide directions and possible answers to the issue of the dynamics between relationship duration and level of trust, and the role of trust in the maintenance and/or dissolution of an established organizational buyersupplier relationship.

\section{Background}

The role of trust in relationship continuation and termination is an intriguing but understudied topic. A review of recent work indicates that trust in marketing has been largely viewed as a construct that increases commitment (Morgan \& Hunt, 1994), satisfaction (Andaleeb, 1996; Anderson \& Narus, 1990), cooperation (Anderson \& Narus, 1990; Morgan \& Hunt, 1994), performance (Dahlstrom \& Nygaard, 1995), signals long-term orientation (Ganesan, 1994; Zhao \& Cavusgil, 2006), and propensity to stay in the relationship (Anderson \& Weitz, 1989). A few researchers have reported less positive correlates of trust. For example, Moorman, Zaltman, and Deshpande (1992) reported that trust between partners declined as their relationship evolved. The authors explained their results by proposing that clients may come to believe that certain service providers in long term relationships are taking advantage of the trust between the two parties, thus acting opportunistically. Grayson and Ambler (1999) replicated the Moorman et al. study in an English advertising industry setting. They found similar results but failed to explain them using opportunistic behaviors. As a result, growing evidence suggests that trust can help a relationship to prosper and at the same time can have "dark side" implications, leading to substantial damage to one or both parties involved in the relationship. These arguments need further empirical investigation.

In addition, as detailed in the following sub-sections, past studies report conflicting findings and conclusions regarding the "consequences" of trusting relationships. There is a need for a more penetrating, in-depth exploration of relationships between the duration of the relationship and level of trust, and the level of trust and relationship behavior. In this section, we briefly review the understudied and often conflicting conceptual and empirical studies related to the length of the relationship and level of trust, and the level of trust and relational behavior.

\subsection{Length of relationship and level of trust}

A number of studies in the past have examined the relationship between time and trust. Ganesan (1994), for example, studied buyer's trust in the supplier through the duration of a relationship. The author hypothesized that a retailer's experience with a vendor is positively related to retailer's trust in the vendor. The results showed that a retailer's experience with a vendor did not have a significant effect on the retailer's trust in the vendor. Contrary to some previous studies (e.g. Anderson \& Weitz, 1989), the author did not find a significant positive relationship between the length of the relationship between partners and the level of trust retailers had in the vendor. In another study, Kumar, Scheer, and Steenkamp (1995) hypothesized that relationship age would have a positive impact on relationship quality. In this study, relationship quality was composed of trust in the partner's honesty, benevolence, commitment, expectation of continuity, and willingness to invest. The authors reported that, contrary to their hypothesis, no main effects of relationship age on relationship quality were observed. Indeed, all the other hypotheses related to relationship age were rejected. Moreover, Handfield and Bechtel's (2002) study found that the long term relationship between a buyer and a supplier based on formalized contracts "had little effect on the level of trust the buyer placed in the supplier" (p. 375).

These intriguing results might be explained in different ways. Perhaps buyer's trust has very little to do with the accumulation of direct experience. That is, trust may be independent of the duration of direct experience and hence, trust may even exist without direct experience (Ekici \& Sohi, 2000). Perhaps, contrary to the findings of the existing literature (e.g. Anderson \& Weitz, 1989), the level of trust between parties has little to do with their intentions to stay in the relationship. Trust may increase or decrease, but it may not be related to relationship intentions.

Other studies suggest that there may be a negative correlation between relationship age and trust. For example, Moorman et al. (1992) suggest that the length of the relationship may be negatively correlated with the level of trust exchange parties have for each other for various reasons. For instance, as exchange parties acquire knowledge about each other over time (i.e. high levels of experience with each other), the buyer feels that the supplier has lost its ability to be objective. Further, the buyer may feel over time that the supplier has become too similar to them, so that they cannot be counted on to add any value to their business anymore. As a result, the buyer may begin considering changing its supplier. Third, as the relationship between buyer and supplier grows, a buyer's expectations about supplier performance increases, which in turn increases the possibility of dissatisfaction with the supplier's performance. Finally, and perhaps most interestingly, the length of the relationship between parties may increase the risks and vulnerabilities of the buyers, create opportunities for opportunistic behavior that creates distrust and reduces the level of trust.

Grayson and Ambler (1999) replicated the findings of Moorman et al. (1992) in the British advertising industry and reported that the length of relationship will dampen the impact of relational constructs. The authors indicated that this hypothesis is supported for trust, which is a significant predictor of marketing services use in short relationships but not long ones. As far as interactions go, the authors report that interaction is (marginally) significant in long term relationships, but not in short ones. Contrary to the conclusions of Moorman et al. (1992), and parallel to the traditional transaction cost paradigm, in the replication study, the authors reported that greater trust is associated with lower (not higher) opportunistic behavior. Recently, Liu, Yuan, Tao, and Wang (2008) reported that the relationship length can reduce the buyer's trust in their suppliers in the Chinese Guanxi context. More specifically, the authors noted that, in time, Guanxi may increase the perceived relational risk and weaken a buyer's trust in the suppliers' competence.

\subsection{The level of trust and relational behavior}

Previous studies offer conflicting findings regarding the level of trust between exchange partners and their relational behaviors. Anderson and Weitz (1989), for example, found that trust increases the propensity to stay in the relationship. Similarly, Kumar et al. (1995) reported positive significant correlations between trust 
(benevolence and honesty) and expectation of continuity (the authors adopted "continuity" items from Anderson and Weitz (1989)).

Dahlstrom and Nygaard (1995) studied the impact of trust on performance in three countries (Poland, former East Germany, and Norway). The authors hypothesized that as the level of franchise interpersonal trust in the franchisor increases, the level of franchisor performance increases. However, they reported that the hypothesis failed in both Poland and Germany and was only supported for the Norwegian sample.

Findings of Moorman et al. (1992) indicate that trust in the researcher does not have a significant direct effect on the utilization of market research. That is, they could not observe a significant relationship between the level of trust and the hypothesized relational outcome of the relationship (the use of research). The authors note that trust "did not have the strongest effect on research utilization. Instead, trust's effects were achieved primarily through critical indirect effects on quality of interaction and research involvement level, suggesting that trust facilitates these relationships processes. That, in turn, encourages research utilizations" (p. 322). The replication study by Grayson and Ambler (1999) reports that neither trust nor commitment is an antecedent of advertising use.

Ryu, Min, and Zushi (2008) investigated the "threshold effect of trust" and reported that "while a lower level of trust may have an impact on a firm's exchange-related decisions, a higher level of trust may not impact decisions once perceived trust is beyond a threshold" (p. 55). These findings are parallel to those of Selnes and Sallis (2003) who argued that lower levels of trust affect a firm's decision making (regarding relational outcomes) while higher levels of trust do not. In another recent study, Suh and Houston (2010) reported that "surprisingly, trust - regardless of operationalization - did not relate positively to the [relational] outcomes [such as commitment and willingness to invest]. Although the preponderance evidence in the literature suggests the importance of trust to B2B relationship outcomes, our exploratory results provide [contradictory] evidence" (p. 748).

A particularly intriguing yet understudied topic in interorganizational relations is the "termination of relationships" resulting from the level of trust between the exchange partners. An influential article by Dwyer et al. (1987) on relationships pointed out the importance of studying relationship dissolution reasons as well as its processes. As indicated by the authors (and we argue that it is still true) little is known about dissolution of inter-organizational relations.

Existing research (mostly in social-psychology and communications) has suggested that the dissolution process can be understood as a reverse of the relationship formation (e.g. Miller \& Parks, 1982), or a unilateral process (Dwyer et al., 1987). According to Duck's (1982) conceptual approach, relationship dissolution begins when one party evaluates his/her "dissatisfaction" with the other party and a cost/benefit analysis could determine if he/she should terminate the relationship. Baxter's (1985) conceptual approach to relationship dissolution consists of two dimensions: (1) direct/indirect expression of disagreement, and (2) "other orientation" (the disengager tries not to harm the other party and finds another partner for him/her before the dissolution).

Trust literature in inter-organizational marketing holds that trust can predict propensity to stay in the relationship (Anderson \& Weitz, 1989) and levels of conflict between exchange partners (Anderson \& Narus, 1990; Morgan \& Hunt, 1994). These studies implicitly maintain that trust explains at least a portion of the relationship dissolution process and lack of trust motivates relationship termination. However, as indicated above, most of what is known about relationship termination is conceptual. We argue that there is a need for empirical understanding of the nature of relationship termination decisions and the role of trust in termination decisions.

In a recent study, Wang and Huff (2007) investigated the likelihood of a buyer's future purchase intentions in the event of its supplier's violation of trust. The authors hypothesized that the future purchase of a buyer from a supplier who violated trust will be lower depending on the magnitude of the violation, cause of the violation, perceived likelihood of future violations, and length of the (trusting) relationship. Their experimental study revealed that the likelihood of future purchases will only be affected by the perceived likelihood of similar violations in the future and the maturity of the trust relationship (i.e. the buyer will less likely to purchase from the supplier in the future if trust was in the early stages of development).

Wang and Huff (2007) offer some evidence for the relationship between trust violations and the future of the relationship based on hypothetical scenarios. However, except for a global theme of "violation of trust," we still do not know what motivates these buyers to decide whether to terminate or continue their relationships with the suppliers. In addition, we don't know whether and how a supplier's (not just a buyer's) "decline in trusting beliefs" (p. 1038) may lead to relationship termination or continuation decision.

\section{Scope of the study}

The findings of past studies illustrate the need for an in-depth understanding about the role and the nature of trust in interorganizational relationships. Fig. 1 illustrates the literature-driven research objectives of the current study.

First, there is a need to separately study the changing nature and the role of trust in short and long term relationships. As indicated by Grayson and Ambler (1999), "longer relationships are qualitatively different than shorter ones" (p. 139), suggesting the value of research that emphasizes either type of relationship. In addition, as pointed out by Seppanen et al. (2007), "temporal dynamics and level of analysis in inter-organizational trust seem to be a fruitful area for further research, with consequent implications on the development of suitable metrics" (p. 261). In the current study, we investigate qualities such as trust and relational behaviors for both long and short term ongoing relationships and identify their similarities and differences. Our findings can offer new insights into the measurement efforts of trust research in inter-organizational settings. In this paper, the phrase "short term" refers to relatively new relationships, and the term "long term" refers to older/more mature relationships.

Second, both Moorman et al. (1992) and Grayson and Ambler (1999) studied buyer's trust in the supplier (users' trust in the researcher and clients' trust in the ad agency, respectively). As recognized by Moorman et al. "our study is concerned with users' trust in the researchers, but researchers' trust in users may also be important to the productivity and longevity of the relationship...Future research, then, could examine whether and to what extent researchers' trust in users affects research utilization" (p. 325). Most research, to date, has dealt with the buyer's trust in the supplier (e.g. Ryu et al., 2008; Wang \& Huff, 2007; Zhao \& Cavusgil, 2006) and relatively less attention has been paid to the supplier's trust in the buyer. In order to fill this knowledge gap, in our study, we examine the nature of trust

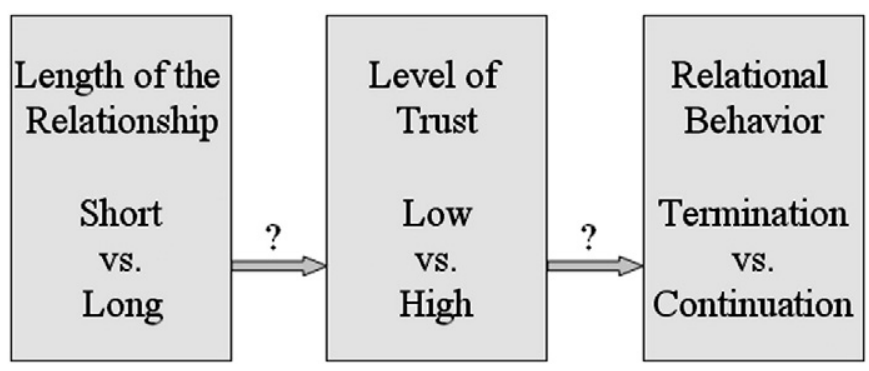

Fig. 1. Focal questions for the current study. 
in long and short term ongoing relationships from both buyers' and suppliers' perspective.

Third, a review of the overall findings of past studies suggests inconclusive (if not conflicting) results about the differences in the levels of trust between shorter and longer relationships. These results suggest that the nature of relational dynamics in ongoing interorganizational exchanges remain unclear. The approach we use in our study can provide valuable insights into these elusive dynamics, by examining, in-depth, how both exchange partners view trust in ongoing relationships.

Fourth, as can be seen from the above review, researchers to date have primarily examined the dynamics among relationship age, trust, and behavioral outcomes within a limited number of industries (and primarily in services settings). We do not suggest that this approach is a drawback; however, we argue that the value of the arguments made by the above studies can be enhanced when other types of exchange relationships are considered. The review article by Seppanen et al. (2007) also points out the preoccupation with certain industries by stating that, "the majority of the [trust] research contexts seemed to be technology-intensive. Technology and risks are often related, and therefore trust is a critical concept in technology-intensive industries, which is where most of the articles were focused. In today's global and networked economy even 'more traditional' industries are dependent on partnership and foreign cooperation, and empirical studies should not ignore them" (p. 251). In the current study, we examine the dynamics of exchange relationships across industries. Further, our investigation provides insights from both services (such as an advertising agency) and goods (such as a beer distributor) settings.

Fifth, one of the behavioral consequences of trust (or lack of trust) in inter-organizational relations is the "termination" of the relationship. As argued earlier, our understanding of relationship termination is limited, and mostly conceptual. Empirical studies so far have focused on important yet rather a limited set of issues (such as resource fit and perceptions of betrayal) related to relationship dissolution (e.g. Seabright, Levinthal, \& Fichman, 1992; Wang \& Huff, 2007). Our study attempts to contribute to the relationship dissolution literature by investigating the conditions under which buyers and suppliers terminate their relationships in the event of little or no trust in the other party. In other words, we aim to understand the conditions that can lead to the termination of an untrusting ongoing relationship, as well as the factors that contribute to the continuation of untrusting relationships.

\section{Methodology}

In this research, we utilize interpretive methodology and its associated (qualitative) methods. Interpretive methodology is increasingly accepted among social scientists (e.g. Knorr-Cetina, 1981; Latour, 1982; Zuckerman, 1988) as well as among the researchers in organizational (e.g. Astley, 1985; Daft, 1983; Sandberg, 2000; Weick, 1989) and (trust-related) inter-organizational studies (e.g. Bunduchi, 2008; Finch, Wagner, \& Hynes, 2010). Qualitative methods such as ours, have the potential for shedding light on contradictory findings (Pratt \& Rafaeli, 1997), revealing intuitive, intriguing research agendas (Price \& Arnould, 1999; Sandberg, 2000), facilitating discovery (Rafaeli, Dutton, Harquail, \& Mackie-Lewis, 1997), and "providing opportunities for advancing knowledge" (Locke \& Golden-Biddle, 1997, p. 1029).

\subsection{The study and data collection}

In order to shed light on unresolved questions about the nature of trust in ongoing inter-organizational relationships, we conducted a series of in-depth interviews. In the following section, we report the findings of these interviews, conducted primarily with middle-scale businesses in a U.S. Midwestern city. Informant profiles are shown in Appendices A and B.

A combination of convenience and snowball sampling techniques were used to select informants. Two blocks of in-depth interviews were conducted: one with buyers and one with suppliers. An initial telephone or personal contact was established for the recruitment of either a supplier or a buyer. In the case of a supplier interview, we indicated that we would also like to interview one of the supplier's customers about trust in exchange relationships. Upon the provision of a buyer name (by the supplier), we conducted a second interview with that buyer. Similarly, when a buyer was first to be interviewed, he/she was asked to provide a supplier's name for a follow-up interview. All potential informants were told that the study was about the role of trust in organizational buyer-seller relationships, and that we are trying to gain a better understanding of the meaning of trust between suppliers and their clients. Although the buyers and suppliers were in a relationship with each other, the focus of our interview went far beyond their relationships, to include their history of relationships with many other exchange partners. Our interest was to sample buyers and suppliers equivalently across a range of industries and types of relationships.

\subsection{Data analysis}

Our analysis of the interview data, consistent with analysis of qualitative field studies, is an emerging product of a process of gradual induction (Lofland \& Lofland, 1995). This analysis process is open-ended and creative. Although there are various alternatives for analyzing qualitative data, literature does not favor a particular analysis technique. In other words, there is no single way to achieve analysis.

Among the analysis alternatives, we use a combination of open coding and axial coding (a.k.a "social science framing") Miles and Huberman (1994) suggest, "coding is analysis...Codes are tags or labels for assigning units of meaning to...information compiled during a study" (p. 56). Further, as indicated by Charmaz (1983), codes serve as "short hand" devices to label, separate, compile, and organize data. Codes also summarize, synthesize, and sort data observations. "By providing the pivotal link between the data collection and its conceptual rendering, coding becomes the fundamental means of developing the analysis" (p. 112). Parallel to these comments, we examined informants to identify prominent themes and associations between themes. A filing system was established, including indexing, coding, and categorizing. Following the suggestions of Miles and Huberman (1994), we used codes as "efficient data labeling and data-retrival devices [because] they empower and speed up analysis" (p. 65)

This coding and labeling scheme enabled us to pursue a social science framing through axial coding of our data (Glaser \& Strauss, 1967; Lofland \& Lofland, 1995; Miles, 1984). The social science framing concept is based on trueness, newness, and importance of the "generic propositions" derived from the data. Generic propositions are answers to questions posed about a topic. Using this social science framing, we attempt to "provide general interpretations, developing theses, formulating concepts, making assertions, and addressing problems" (Lofland \& Lofland, 1995, p. 182) posed through our literature review.

\subsubsection{Coding and labeling: categories and themes}

The first part of our analysis involved scanning all the data (a total of 521 single-spaced pages of interview transcripts) and searching for dominant and emerging themes from the semi-structured interview script categories. More specifically, each section presented in the Findings section reflects an emerging theme/pattern and given the data-set, it provides details about this emerging theme/pattern. "Dark-side behaviors," "continuation behaviors," and "termination 
behaviors" are examples of such emerging themes/patterns. Each emerging theme has its own specific components. For example, the "dark side behaviors" (as an emerging theme) has many different specific components experienced by different informants. Not all informants experienced/reported the same dark side behavior. Some experienced "betrayal" others experienced various forms of "disappointment" ( 5 forms of "disappointment" were identified). In the end, all of these specific components take us to the common emerging theme called "dark-side behaviors" of trusting relationships. In summary, in order to determine the codes and categorizations, we relied on open-coding procedures in that we employed both intra-text analysis (coding of each interview script individually) and inter-text analysis (finding commonalities of the codes across many different interview scripts).

\subsubsection{Axial coding, social science framing and conceptual structure}

The next stage of our analysis involved searching for a data-driven conceptual structure that would integrate these categories and themes in a coherent manner. To do so, once codes and categories are established through open coding, we turned our attention to axial coding. The purpose of axial coding is to identify relationship among various open-coded categories and any other sub-categories that would have emerged (Strauss \& Corbin, 1990). In the axial coding, the analysis turns intensive around one category at a time and relationships and patterns in the data are identified. Our objective in the paper was not to propose a framework in a positivistic manner, rather to articulate an emerging framework that would help us understand and provide an in-depth description of some of the dynamics associated with inter-organizational relationships. We summarize the results of axial coding in our emerging framework (Fig. 2). This figure serves as a general guide to the discussion of our findings in the next section. We return to an evaluation of this figure in the "Discussion" section.

We followed the suggestions of Glaser and Strauss (1967), Miles (1984), and Strauss and Corbin (1990) in developing this framework. Three questions guided our assessment of the framework: (1) Does the framework capture a large number of themes? (2) Is the framework a cohesive and parsimonious summary of the themes? and (3) Does the framework offer new conceptual insights about inter-organizational relationships? Trustworthiness of our open and axial coding procedures and the resulting categories and relationships among categories were established through both peer-checks and member-checks (Lincoln and Guba 1985; Wallendorf and Belk 1989). With respect to peer-checks, emerging themes were discussed with three other marketing faculty members and two of them (who are experienced in qualitative methodologies) were asked to analyze (open-code) a sample of six interviews. We crossed check our findings with their coding exercise for consistency. In addition, two buyer-informants and two supplier-informants were recruited in the advanced stages of the data analysis to perform member-checks. These recruits were asked to evaluate the findings (our categorization and the inductive model) using their experiences. Member checks confirmed the relevance of our key findings.

\section{Findings}

The findings are structured around our main research questions: $1-$ whether and how nature and the role of trust differ in short and long-term relationships (Section 5.1), and 2-what are the behavioral consequences of high and low levels of trust in buyer-supplier relationships. The second research question is examined based on the following sub research questions: a-what are the negative consequences (i.e. "dark sides") of high trust relationships (Section 5.2), and bunder what conditions low trust leads to relationship continuation (Section 5.3) and/or relationship termination (Section 5.4).

\subsection{Trust in short versus long term partners}

One of our objectives in this study was to investigate whether buyers and suppliers view differences in the trust they have for short term versus long term partners. Both buyers and suppliers were asked

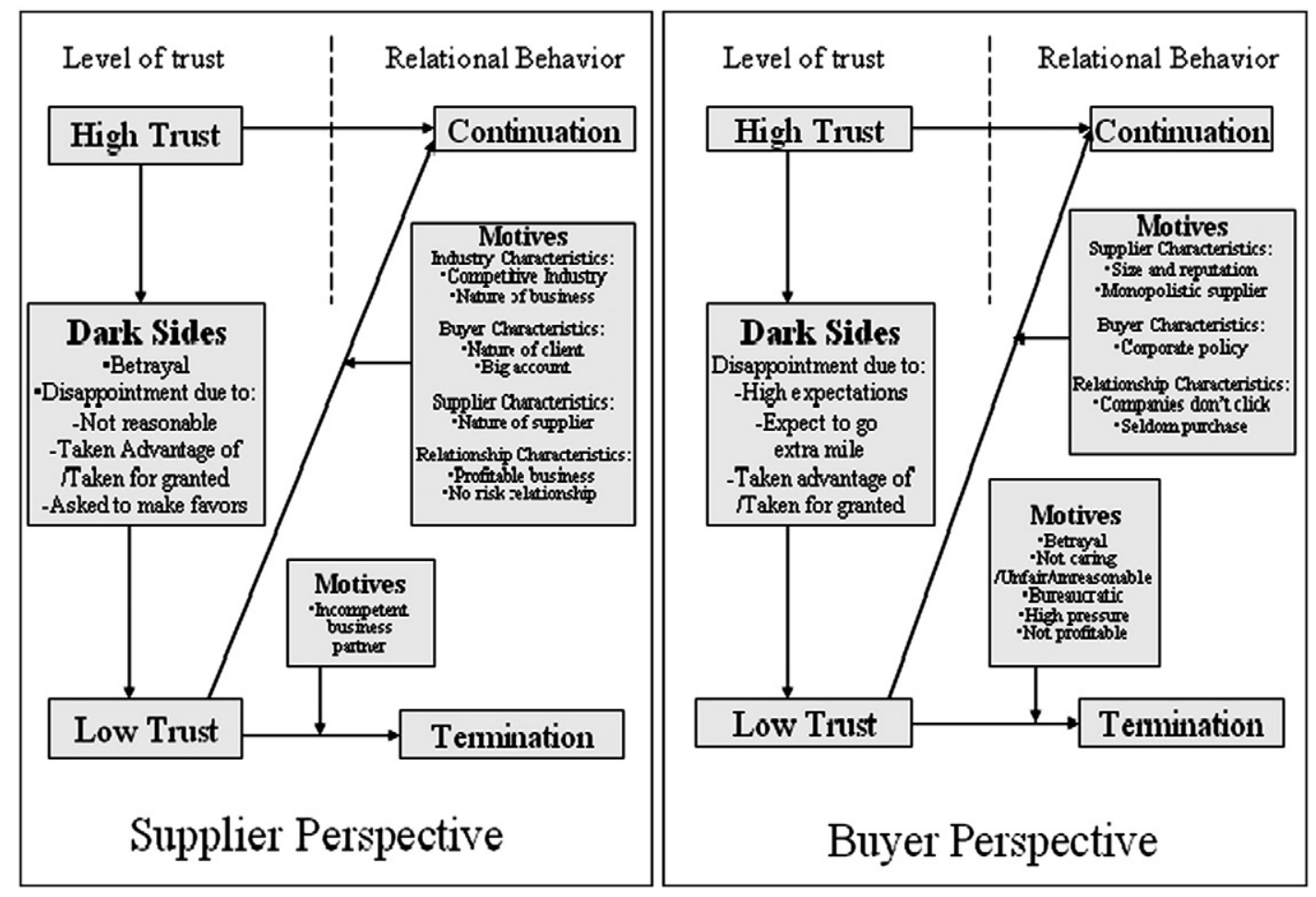

Fig. 2. Emerging model of buyers' and suppliers' perspective on the outcomes of high and low trust relationships. 
if they think trust differs between long term and relatively new suppliers (buyers). Without any exception all suppliers indicated that trust DOES differ between long and short term partners, indicating that they have higher levels of trust with longer term buyers. Thus, areas I and IV (of Table 1) appear applicable to our supplier informants. Area II (high trust in short-term business partner), however, does not seem to apply to the suppliers. They tend to make a conscious choice between their short and long term customers. Evident in many of these supplier interviews is an active, construction metaphor-they are working to "build trust" over time. Also apparent in these interviews is a stretching of the relationship from business to friendship, and a general mixing of trust and other relationship factors. The following informant comments are illustrative.

...there is, in the beginning because you don't have, you've not really established that trust yet or that personal relationship yet with that brand new customer and you have I've got ten years with Teri and so you know of course I've got more trust with him then I've got with the new guy..."(S8)Hmmmm, well yeah I think so to a certain extent just because it becomes more of a friendship than a business associate. So the newer ones you might still be working on to build it whereas, your older ones you've been there and it's established. (S22)

The buyers, on the other hand, frequently indicated that trust DOES NOT differ when they think about long and short term suppliers. In contrast with suppliers, the buyers more often view trust as a product/service attribute-part of the exchange package. In addition, they are less inclined to use a construction metaphor, and instead, often view trust as something that is either there or isn't-a kind of instant connection. The following quotes are indicative of buyers' perceptions.

No, personally I don't. I think that trust is trust and if I'm going to do business with somebody I have to trust them whether it's for one year or whether it's a ten-year deal... I want to do business with somebody I trust, either long-term or short term. (B16)No. If I trust one of my reps, I trust them no matter how long I have known them. (B23)

Our findings offer a counterargument to Ganesan (1994) whose findings did not show a significant relationship between a vendor's experience with a retailer and the vendor's trust in that retailer. Ganesan (1994) measured experience based on the length of the relationship in years. The vendor's trust in the retailer and the retailer's trust in the vendor were measured separately with the assumption that the domain of trust remains primarily the same across both types of respondents. Based on our findings, it is plausible to argue that the differences in views by buyers and sellers can be traced back to their notion of trust. Differences in their views of trust might suggest that the domain of trust changes between buyers and sellers, and therefore, the items used to measure buyers' and suppliers' trust should reflect these differences. For example, as will be discussed later in more detail, buyers seem to view trust more as an economic-performance related concept, and therefore, with respect to trust, buyers expect all their suppliers to offer a similar performance. These two buyer comments echo many others.

Not really. I expect similar performance from all of my suppliers so I don't see why it (trust) would change if they were old or

Table 1

Length of business relationship and level of trust in exchange partner.

\begin{tabular}{lll}
\hline & Low trust & High trust \\
\hline Short term & I & II \\
Long term & III & IV \\
\hline
\end{tabular}

relatively new (partners)...(B15)I don't think it should differ, I would like to think that they're obviously in business for the same reason as all of my long-time suppliers are too...I'd like to think that all of those guys are in business for the same reasons that are functional within that particular business. (B18)

In summary, for the buyer informants, the distinct areas of Table 1 may not be very illustrative. As will be discussed in Section 6.1., the buyers may have high levels of (pre-relational) trust for certain suppliers, and as a result, may report high levels of trust for both their new (Area II) and long-time (Area IV) suppliers. In addition, as will be explained in Section 5.3, both buyer and supplier informants have long-term business partners that they have low/no trust (Area III). However, for a host of reasons, explained in Section 5.3, both buyers and suppliers continue their low/no trust business relationships.

\subsection{Negative consequences of high trust: the dark sides}

In our study, we conceptualize dark side behaviors of a trusted exchange partner as those that eventually cause problems to the other party and/or harm the business of the other party. Literature on the dark side of trust has primarily focused on "betrayal" (e.g. Jones, Cohn, \& Miller, 1991; Metts, 1989; Miller, Mongeau, \& Sleight, 1986) and relational tensions (Fang, Chang, \& Peng, 2011) as a result of close relationships (Anderson \& Jap, 2005). Due to our broader conceptualization, we identified various categories of dark side behaviors. We also provided detailed and textured accounts for various relationship tension variables suggested by Fang et al. (2011). These categories include betrayal and several expectations and relational dynamics that lead to disappointment, including: setting high expectations, expecting trusted partners to go the extra mile, being asked to do favors, feeling taken advantage of or taken for granted, and being unreasonable.

\subsubsection{Betrayal}

Betrayal is a well-documented dark side consequence of trusting relationships. Therefore, it is no surprise that our findings indicate betrayal. However, we heard betrayal stories mostly from suppliers. Earlier, we demonstrated that suppliers see differences between sort and long term buyers with respect to trust. As the relationship matures, suppliers begin putting more trust in the buyers, share confidential information, and eventually put themselves in quite vulnerable situations. The following excerpt reflects two interesting things we often heard from suppliers. The first is a kind of ongoing interplay of trust and betrayal-we trust them and they betray us, and second, the unintentional (non-opportunistic) nature of client betrayals.

...We've had people in the past and recently we still have people, and we will come out with a new program and we trust our clients, we'll give them information because we know we can trust them but then they go out and tell our competition and then it gets back around and people get upset because one client knew more information than another client. It's a really tight knit industry. You trust someone and they just turn around and stab you in the back even if they meant to or not. (S4)

Further, supplier informants indicate that high levels of trust create opportunities for betrayal, because the supplier believes the buyer so much. In the following interview with a sales rep in an intensely competitive industry, we see not just a betrayal of trust, but what the rep sees as a betrayal of a "good relationship." Notice again, the expectation that this is what happens-an expected interplay between trust and betrayal, rather than a specific, unusual case of betrayal. 
You know I would say there are times when people tell you something you tend to believe so much that you have a hard time believing when the opposite happens. Sometimes you have so much trust you think they don't have any other alternatives when in fact they do whether it is because of new technology or whatever and they buy a competitive product. It's tough when you have a really good relationship and they buy competitive products or support competitive programs that are hard to swallow. (S2)

\subsubsection{Disappointment}

When they go into a business relationship, exchange partners set and/or form expectations about the performance of the other party. Their trust of each other elevates and/or leads to new expectations. They set high expectations for each other, may put their businesses at risk, and when these expectations are not met, their businesses may be harmed. In our interviews, we observed several types of expectations and relational dynamics that led to disappointment.

5.2.2.1. Setting high expectations. Although buyers see taking risks as a part of their business, it appears that they take chances on new products based on their trust in the supplier. In other words, their trust in a supplier might lead buyers to set high expectations for the performance of a new venture. As can be seen from the following example, when the product does not perform as hoped, trust in the supplier could potentially harm the buyer's business.

Well, sometimes you might set your expectations too high on someone. For example, a supplier brings in a new product, like a Christmas beer, and you hear up and down that it's good, and it is working well for all the restaurants or bars. And, uhh, you then bring it in and it turns out to be different than your expectations, or it just ends up being a flop for you. I would say that that's really the only thing. But you have to take chances in business, and you have to be willing to try new products. I think that that would be the main way that something could come back to harm my restaurant. (B10)

5.2.2.2. Expect trusted partner to go the extra mile. Sometimes disappointment comes from an expectation that a trusted long term business partner will reciprocate trust. Below is the summary of a long story of disappointment. Due to a long term relationship, a restaurant owner expects a beer supplier to even "go around the law" in order to prevent the restaurant from any potential reputation damage in a bad check incident. The client in this case is disappointed because in a 23 year old relationship, he and his supplier had never encountered such a problem, and he trusted the beer company to behave in his best interest when such a problem arose.

Our bank made a mistake and didn't deposit one of our checks right...Well then we wrote a check to a distributor, a beer distributor in [city name], that the check didn't clear because there was not enough money in that account. Well then the beer distributor, who will remain nameless, well their name was [distributor name], they at that point cannot legally sell us beer without it being paid for at that time. I understand that, that is the law. Well they went further and they called up the different liquor purveyors in and said [buyer name] is writing bad checks...They refused to ship beer to us. So did another company because they thought that was the law. It was a fiasco. After doing business, we have done business in [town name] with that same company, same ownership for 23 years, never had a problem. Not one problem... Instead of giving us the courtesy, instead of calling and saying, "Matt this is abnormal, something happened, can you check into this and give us a call back because as of this time we can't sell you alcohol or we have to have cash or we're going to have to call these other people, whatever it is, but we'll give you until this time." They didn't even give us the courtesy of doing that; instead they just drug our name through the mud...That is the worst kind of reputation to have, that they don't pay their bills, much less on time, they just don't pay them, their checks are bad. So it was a big deal to us. Until I contacted my boss weeks later, much after this had all been resolved. I told him the story. Then he called the owner of [distributor name], who he knows very well, and then this guy called me back, sucking up to me. It was too late at that point. (B21)

5.2.2.3. Asked to do favors. Another related dark side of trust is asking special favors due to a long term relationship between buyers and suppliers. The difference between this category and expecting a trusted partner to go the extra mile is that, here, the long term relationship is not only based on business interactions but also based on personal interactions (i.e. friendship). Many commercial exchanges develop into friendships, and friends are expected to do favors (Price \& Arnould, 1999). As we will discuss later, especially when friendship is involved, one party may assume that he/she can stretch the relationship to a point where the other party actually becomes financially worse off. This is perhaps the most powerful and potentially most damaging dark side behavior, yet it has received little empirical attention. Although we heard several similar stories, the excerpt below is one of the best for describing the emotional commitment and the ongoing dynamic of trust and betrayal.

Yeah, I knew this guy for a long time, 25 years, and he had had a restaurant and was doing well and I was his sales man, and he let his wife pay the bills and she had never done this so now he owes us a lot of money and I say you know you have got to do something about this, and he says I've known you for 20 years, you know I will never burn you, and I said okay prove it to me, and my management went in and worked out a deal with him and he paid it off and okay, we're smooth. He sold that restaurant, and started a new one and everything was going fine, and then he got a divorce, and I should have known at that time, okay, maybe I got to pull back on the friendship thing, I mean I went to his wedding and the whole works, and uh, so I went to him and said hey, things aren't good, I know that, but do I still have the same promise that you won't burn me, and he said oh, yeah I won't. Well, he did for $\$ 3000$. So, he filed chapter 9 protection from creditors, and there is not money to get, he owed a lot and he paid off who he had to and nothing to me. It does cost you sometimes to trust. (S26)

5.2.2.4. Taken advantage of/taken for granted. Moorman et al. (1992) suggested that one of the reasons why the length of relationships may be negatively correlated with the level of trust is that the supplier firm becomes similar to the client over time and may begin to take the relationship for granted. Our findings support this notion. In the following example, the buyer trusts the supplier to give the best price available in the market. However, the supplier believes he doesn't have to offer the buyer a lower price because the relationship between the two has already been established.

Yes, it has. (long pause) Specifically, one of my suppliers had quoted me some pricing. I'll use dollar figures. He quoted me a specific price of five hundred dollars on a certain item. I found out a few weeks later that he had offered a better price to another customer. In which case, I assumed I was getting the best price available. After I had confronted him, he went on to explain that even though we were a larger customer, the other customer out there screamed a little bit more about the price. That's when I told him flat out, again this is when we were honest with each other...he 
said I had to do what I had to do to get the business. I said from this point on I want you to do what you have to do to get my business because I will take my business elsewhere if this continues to happen. I don't want to sit here and ask you is this the best price you can offer every time; I shouldn't have to. It should be a situation where they know I want the best price and they will do what they have to do to get me the best price. If they can't, then they don't go down the street and offer something better to someone else just because they scream a little louder. (B27)

It appears that both buyers and suppliers can be taken advantage of by their exchange partners when they "have more trust than they should have." Implied motives for this dark side behavior appear opportunistic and provide a rationale for the control mechanisms of transaction cost economies. In the previous example, the buyer makes it clear that he doesn't want to be a watchdog and monitor prices. In the following example, the buyer believed that he didn't have to check for the prices offered to various other customers in the same region because he trusted his supplier to follow the pricing standards established in the industry. Once he finds out that he is being taken advantage of because of his high trust, he becomes a watch dog (uses control mechanisms) for their relationship.

From time to time throughout all of my business years, yes, I have had situations arise where I went into dealings a bit too blindly just because I did have more trust than I should have...And, from time to time, I guess I feel I have been taken advantage of to a certain extent. The incident I am thinking about, we reconciled the situation and I am still doing business with that company...I have a couple (more) of them, since we are talking about [supplier name] here, I buy a certain amount of gas products from them acetylene and oxygen I resell and use some of it myself. Well, it went along for many years and the price, as with anything, continued to go up as with anything, and along came a couple of the vendors in that same line that came up from Missouri and Iowa that tried to break into the southeast Nebraska market. Well, as they came around, they were telling me all of these stories about how cheap their gases were compared to [supplier name]. I finally called them on it and they reduced their prices across the board. And, of course, I was a little grumped. I didn't think I needed to be quite that much of a watch dog on that sort of thing. If they were so willing to drop their prices after a little bit of competition, then they were probably making more than their fair share of profit margin prior to that. (B18)

As the following excerpt demonstrates, at times, buyers begin to take advantage of long term suppliers. In this next case, the supplier believes that the buyer hides some important information in order to delay the payment, and in doing so the buyer assumes that the supplier would not check for the accuracy of the situation because the supplier places high trust in the buyer.

I have a customer now that has been a longtime customer that I'm beginning to feel I don't trust. They used to pay their bills on time, but now we have a bill that they aren't paying because they said they were waiting on some government funding on a cost share project, and that the organization is just slow in getting things done. Well we happen to know of another customer that applied for cost sharing after they did, and have already gotten their money. So I have lost my trust in them because I think they are lying to us. (S33)

In the first two cases, the buyers believe that the suppliers are acting opportunistically, but in the third case, the buyer's motives are less clear. The buyer may believe that because he generally pays his bills on time, he should be trusted, while the supplier feels he is being taken advantage of. This thin line between reciprocating trust and being expected to go the extra mile or being taken advantage of by a long term exchange partner is a consistent theme in our data.

5.2.2.5. Being unreasonable. A final, and less common, theme of disappointment relates to violations of basic exchange courtesies. Certain minimal expectations apply to any exchange partner, and suppliers and buyers are disappointed when these reasonable expectations are not met. In the example that follows, the supplier went out of his way to service a client, only to get a lawsuit filed against them. In this and other cases, exchange partners were disappointed because of what they viewed as violations of the basic cultural norms of exchange.

Yes, I can think of an example without even thinking too long about it...In this case it would be harmed as effecting our reputation. Explain? Oh my, that could take a while, but I'll make it short. Um, a customer was out of water, we serviced their well, and now we are being sued because he had cattle die from thirst. First of all the cattle were so gaunt before we got there that they were about dead anyway. But what I'm trying to say, is when the lawsuit is filed against us, it is in the paper for everybody to see. People wonder what we did, then people talk. I guess something like this can harm your reputation in some ways. (S33)

This section suggests that many different relational dynamics lead to feelings of betrayal and disappointment. However, as evident in several of the cases above, these feelings of betrayal and disappointment may or may not lead to a termination of the relationship. They may come to be an expected part of business relationships. Moreover, disappointment and betrayal may unfold in a repeating pattern of trust and betrayal, re-establishment of trust and subsequent betrayal. In the next section, we look at factors that contribute to the continuation of relationships in which there is little or no trust.

\subsection{Continuation of low/no trust relationships}

The literature has suggested that as the duration of the relationship increases trust between exchange partners may diminish. Further, reduction in the level of trust in the other party might lead to the termination of a long term business relationship. Our results suggest that low levels of trust (or no trust) may not lead to the termination of the relationship. Both buyers and suppliers indicated that they have long term business partners they don't trust. In many ways, these results are not surprising, although, in an era focused on trust and relationship building, it's crucial to remain aware of the myriad of other factors that influence whether exchanges continue. Our data indicates that trusting relationships are desirable; however, trust may not necessarily be a relationship quality that keeps exchanges going. For various reasons, our (buyers and seller) informants continue doing business with each other although they don't trust each other. We separately examined these motives for buyers and suppliers.

\subsubsection{Buyer side}

In this section, we discuss buyer motives to continue a no/low trust relationship in the following three distinct categories: supplier characteristics, buyer characteristics, and relationship characteristics

5.3.1.1. Supplier characteristics. Some buyers have partners that they don't trust, but do business with for a long time because the supplier has a strong, reputable company with a recognizable name. Prior research suggested that size and reputation could determine which supplier will be selected for the next purchase (e.g. Doney \& Cannon, 1997; Hill, 1990). Further, Ekici and Sohi (2000) argue that size and reputation of the supplier could initiate a relationship. The above articles indicate that size and reputation can speak about the 
(positive) credibility of the supplier, therefore, the supplier could be trusted. In the current study, we are suggesting size and reputation, not as a source of credibility, but a source of power. Due to the perceived power of the exchange partner, the buying firm is willing to continue doing business with a supplier, even though they don't trust the supplier. In the following excerpt, the buyer feels pressure from her customers to carry a brand from a company she doesn't trust.

Um, yeah, we have a company that, um, I won't mention the name. (laughter) But we have a company, that is in clothing and they are a strong company, with a very recognizable name. Um, and they do a good job, but there are several times throughout the year, where we end up not getting necessarily the product, the exact product that we wanted. Um, they may fill us incorrectly, you know, or we've been quoted a price and we get billed for a different price. Something like that, um, and that's one that we kinda look at and, it's a, again it's a very reputable company. People come in and ask for things by that name. Um, so you have to look at that also. It's not one that you can just yank lightly, you know, oh, well they've not done what they said they would do, you know, and it's happened 5 times this year, so we're not going to carry their stuff anymore, because in the long-run that would hurt our business, you know on the flip side... (B1)

In extreme cases, exchanges continue because buyers feel completely dependent on suppliers, and feel they have no choice. Notice that in the following excerpt, the buyer first generalizes the problem and then gives an illustration. In this instance, the buyer feels that the supplier doesn't care, because his business doesn't really matter to the supplier. Parallel to earlier illustrations, because there is no "trust factor," the buyer feels required to monitor against opportunistic supplier behavior, such as throwing "their weight around."

Yeah, there are definitely suppliers I have done business with for a long time that I don't trust, but because of certain circumstances, we have to do business. Going back to the grocery industry, I had a supplier from [supplier name], one of the biggest companies in the country and they like to throw their weight around; our business to them was nothing. For him to worry about what I did or didn't do was not a big deal, and I knew that. So, (pause) with him and his company we never did develop a trust factor. It was always a "trust but verify." But because they were the only manufacturer of products that we needed, I had to do business with them; I had no options. So yeah there were definitely those suppliers we did business with even though we did not trust them. We didn't want to do business with them, but because of some certain circumstances; we had to. (B27)

Implicit in both of these informants' reports is that although they don't trust the supplier, their customers do. This both raises a provocative problem, and a theme from the supplier side of our data. There is an implicit assumption that companies can deliver trust to all of their customers, but our supplier informants stressed that trustworthiness is a costly and scarce resource. Sometimes, suppliers feel that they must choose how to manage their trustworthiness.

5.3.1.2. Buyer characteristics. A buyer may continue doing business with an untrustworthy supplier because of corporate policies. For example, this restaurant owner feels frustrated with a particular supplier relationship, and describes his helplessness when the home office makes "tying" agreements with that supplier. Although the buyer feels willing to pull his customers toward different brands, the home office is unwilling.

Some of it is just kind of company oriented. I have to order certain types of tequila or liquor. Being a Mexican restaurant, our number one seller is margaritas. I have to use special brands. For instance, the other lady, I've already tried to get into business with, she doesn't sell that particular brand. I'm trying to push our company's home office to change brands so that I can work with her, but I haven't gotten anywhere with it. I'm really not left with a whole lot of choices. So I try to keep it the best kind of relationship that I can. (B10)

Corporate headquarters may feel quite content with their overall relationship with this supplier, and in fact, other locations may have excellent relationships with their particular representatives. As in the previous discussion of supplier characteristics, our findings emphasize the importance of considering how trust operates between a supplier and buyer at several different contact points.

Several buyers and sellers suggested that they are the type of people who trust others, even when that trust is betrayed. Some suggest that the nature of business is to trust, even though betrayal is an inevitable consequence. Because this characteristic was much more pronounced among suppliers than buyers, we discuss this issue more in Section 5.3.2.

5.3.1.3. Relationship characteristics. Besides buyer and supplier characteristics, the nature of a supplier relationship may give buyers reason to continue doing business. In such situations, it appears that buyers' and sellers' business objectives do not quite match ("companies just never click"). However, buyers accept these situations as natural, and therefore do not consider terminating the relationship. Implicit in the following quotation is the interaction between corporate policies, company objectives, and the relationship that forms in the field. Although a supplier representative and/or the company he/she represents may be very trustworthy, other economic factors may be more crucial in the exchange relationship. Similarly, a lack of trustworthiness may be less significant than other economic factors. For this informant, as for many others, discussions of trust and the relationship are bundled together in an inseparable whole.

Again, you've got certain companies that have better relationships with other companies. [Supplier name] for instance and certain manufacturers at the corporate level have got very good relationships. By the same token, there are other manufacturers that don't have good relationships. So, it's kind of a funnel down affect. We are actually told in some cases with certain manufacturers that for whatever reason, it might be we're simply not profitable with their product, that may have nothing to do with personnel or something, it might just be direction. In those cases it's the same way with the competition, they may have an excellent relationship with a company we don't. The two companies just never click and therefore it's really tough for the people at our level in the field to click, because we're basically given a statement that we really don't want to work with this company. (B2)

Besides the quality of the relationship, sometimes the level of interaction is low, and trust is perhaps both less likely to develop and less relevant. When the purchase relationship is not so frequent, buyers may keep the business relationship alive, even though they do not feel much trust in the supplier.

Q: Just to clarify: So you continue doing business with them, but don't feel you have a great deal of trust in them?I: That would be correct, but only because they just sell me a particular product on an as-needed basis. If I run low of that product, I just call them up. (B18)

The idea that trust matters more in certain relationships than in others may not be new. However, focusing on ongoing interorganizational exchanges where trust doesn't matter much would offer a contrast with current research that tends to focus on settings where trust makes a difference. 


\subsubsection{Supplier side}

Our research suggests that from the supplier's perspective there are four types of reasons for the continuation of untrusting relationships: industry, buyer, seller, and relationship characteristics.

5.3.2.1. Industry characteristics. In general, the suppliers in our study perceived their industries as highly competitive-leaving a relationship means providing opportunities for competitors to enter already saturated markets. As this supplier indicates, it is hard to walk away from such relationships only because there is not enough trust. Notice again, the metaphor of developing trust, and the way in which trust is bundled with "connecting" or "clicking."

Yea, I would say there are some, I would say I trust everybody to a certain extent. There are some clients you can work with; work with, and work with and they are not going to be able to develop trust. It might be their personality, it might be their business, it might be the fact that the two of you can't connect. It is hard to walk away, especially in this day and age in a very competitive industry just because you cannot click... (S2)

This informant continues his explanation, observing that in a highly competitive business, it seems that suppliers continue doing business with buyers for whom they have low trust, because terminating a relationship may produce "enemies" in the market place. He prefers a relationship without trust to a potentially "negative" relationship.

You got to be able to overcome these things and adjust your personality to those clients. There are times you throw your hands up and say forget it I've done everything I can do to develop a relationship with them and every time they have gone the other way on me you've got to spend your efforts in other areas. But I try not to do that because you don't want to have an outstanding enemy out there. It's one thing if they are not a supporter of you and your company but you don't want them selling against your company. Irregardless of the fact that you cannot develop a trusting relationship with them you do not want to have a negative relationship with them. (S2)

Several supplier interviews suggest that maintaining a relationship under low trust conditions is normal, simply because business works that way. For example, this supplier, although he would prefer his buyers to keep their promises to him, accepts the fact that they may promise one thing and do another. Even though their actions violate trust, and the relationship "takes a hit," the salesperson continues to sell to these clients.

Yes there are clients that I think would... I think it shows most definitely through being a salesperson whom they buy from. If someone whose been my customer for a long time tries or does let's say has a promotion running in his/her business and they choose to buy from different wholesaler or salesman, then they're still my customer and will be for a long time but I think that the trust whether they said that they might use my product or promise me a certain promotion and choose to go with somebody else. They will in turn not end up...they won't not be my customer any more but that relationship will have taken a hit somewhat. (S30)

5.3.2.2. Buyer characteristics. As indicated by Held (1968), trust has more to do with situations of uncertainty than with situations of certainty, or in her words, "trust is most required exactly when we least know whether a person will or will not do an action" (p. 157). On the other hand, when we know, through our long term relationship, and therefore countless experiences, how the other party will react to certain situations, we take our measures accordingly. In the following example, the supplier (an ad agency) does not trust certain long term clients. However, this does not seem to worry him so much because their untrustworthy behavior has become predictable and expected. Since their behavior is expected, the supplier does not consider himself in a vulnerable situation, and does not see any reason to leave the relationship. Again, trust appears to be bundled with the overall quality of the relationship.

Well this goes back to the question that I have been doing business with some of them for so long but I still don't trust them. I still know that every time I put an ad together for them even if they sign it and say "Yeah this is great, go ahead and run with it," I still know that when it comes out on print they are still going to call me and bitch at me, and these are the long time clients too. I just expect it from them. (S4)

Our data indicates that, like buyers, suppliers may also sometimes feel helpless and continue doing business with clients even though they "don't want to," because of the power of the buyers. Suppliers feel that they have an obligation to keep these relationships alive for the sake of the business. This supplier begins by describing a trusting relationship as one where, if things go wrong, the customer is willing to work things out. This is consistent with our earlier discussion of expecting reciprocation of trust such as extra accommodation. He goes on to note that with big accounts, he has to work things out and keep them as customers, even if he doesn't want to.

I: I would say that the example I gave with [Buyer name] where we've been doing business with them forever... but they don't seem, it doesn't seem to be a very trusting relationship based on their actions and what we provide for them. Um..... Another example would be people who we have had for a long time who have been customers for a long time and then one thing goes wrong, they get mad and cancel all their lines, don't pay their bill and then they get sent to collections. I mean that's not a very..., I don't think if they're unwilling to work out one minor detail and just say forget it and move on then I don't think that's a very, I mean, we've had that happen several times too so... I don't think that's very trusting.Q: What makes you want to continue to do business with somebody like that that you don't trust? times you don't, but if they're a big account and have over a specific number of phones. Say they've got ten phones and they are mad because one thing went wrong on one of the bills or something, one phone breaks and they cancel all of them, it's kind of an obligation to try and help them and get them back on even though you may not want to deal with them, but you feel like, for the business sake, it's kind of an obligation. (S12)

In other cases, it is apparent that suppliers, who are keeping such relationships alive, also take personal and emotional "hits" by "swallowing their pride." However, as the example below suggests, these potential personal and emotional damages may lead to the introduction of traditional control mechanisms, possibly increasing the transaction costs.

Um, well that's, you know, one of those things that you got to swallow your pride and go back and...there is one account that I've been screwed over a couple of times and they sell a lot of beer for us so I have to swallow my pride and go back in there. It's just that I'm a bit more leary the next time and say okay I'm going to do this for you but we need to set some guidelines here first so... (S22)

5.3.2.3. Supplier characteristics. Supplier interviews suggest that friendship as well as the supplier's character are important factors that lead to continuing a business relationship, even when clients cannot be counted on to fulfill their promises. This informant interview resonates with many comments we heard from suppliers about their predisposition to trust customers, and to extend courtesies to customers (especially friends) in need. 
It's a customer who owed us money, and he was also a friend. I would call him about paying on his bill, and he said he would get us paid, I promise. Well, I trusted him, and he never did pay the bill. But the family was also going through a divorce and were having financial problems. The father of the client did end up paying the bill, when he heard it wasn't paid. I guess what makes us continue doing business with the guy is that we like him. My husband would do anything for anybody, and that, he carries through in our business. Like he says to me, they are out of water, and they need it. I have commented to him that they don't pay their bills well, and he says we'll deal with that when the times comes. People need water. He just trusts people, no matter what. (S33)

5.3.2.4. Relationship characteristics. Parallel to buyers, several suppliers suggested that as long as the business is profitable and/or has potential to be even more profitable in the future, lack of trust does not lead to the termination of the relationship. For example, this supplier talks about how he does not trust some of his current clients.

Yes, there are some of my customers that I have been dealing with for a long time that I don't trust. The honesty isn't there. They try to take advantage of you all of the time. They are only in the business for themselves. They are just constantly trying to screw me and therefore I have to watch their business very closely and am not allowed to trust them. Real trust is a partnership. You have to work together to get a good trusting relationship and work toward a common goal. If things start to lean one way or the other you start to lose trust.

When we ask, what makes him continue to do business with this client, he replies:

Well, I'm going to do business with this client until it is no longer profitable. Once they begin to take advantage and try to hurt your market of something, then you have second thoughts. This happens but very rarely. (S7)

Another supplier makes it even more explicit that sometimes economic and financial considerations offset relationship qualities such as friendship and loyalty.

Because it is a dollar and cents thing. Obviously we are in this business to make a profit and not everybody whom you do business with is obviously not going to be your best friend, most loyal friend, or most loyal customer if you will and stuff. You do in this business, have to sell a certain amount of merchandise to, ah, pay the bills. (S24)

In other cases, suppliers may be motivated to keep untrustworthy clients simply because they do not perceive any financial risk associated with continuing these relationships. This pharmaceutical company salesperson, for example, has clients (doctors) who apparently lie to him about their usage of his products. However, he still keeps these doctors' accounts.

Are there any client's out there I don't trust that I have been doing business with? Well ya, there are a few doctors... They say they have been using my products for the 18 months I have been visiting them. When you go look at the sales data they haven't been using them, so that is an example for this type of instance. (S23)

\subsection{Termination of low/no-trust relationships}

As evidenced through the above interview excerpts, some companies may continue doing business with partners although they don't trust them. At the same time, organizational buyers and suppliers may terminate their business relationships with partners with whom they don't have any trust. When there is low or no trust, "under what conditions do companies prefer to continue or terminate their businesses" remains an intriguing, yet relatively unanswered question. Our data indicates that one possible overarching threshold for terminating a relationship under a low/no trust condition is the availability of alternatives. Although buyers and suppliers mentioned various conditions in which they decided to terminate an ongoing relationship, in many cases they were able to "walk away" from the relationship, because they "could go somewhere else."

We also observed through our interviews that companies who had to terminate their ongoing business relationships were unwilling to talk about these relationships and their break-ups. We believe that there are two basic reasons for this unwillingness. First, companies don't want to talk about their misjudgments and disappointments. Second, as indicated earlier, some companies continue doing business with untrustworthy partners because they don't want "outstanding enemies" or "negative relationships" in the market. They may fear that talking about these relationships could also create enemies in the marketplace.

Below, we identify specific situations that lead to terminating low/ no-trust relationships. The following themes are identified based on the responses to the question: "Have you ever cut off a relationship with a supplier because you feel you don't trust them?"

\subsubsection{Incompetent business partner}

Competence has been identified as one of the most important building blocks of trust (Barber, 1983; Renn \& Levine, 1991). Barber (1983), for example, describes trust as expectations about competence and fiduciary responsibility. It is also apparent from our study that a lack of competence leads to a lack of trust, and moreover, to the termination of the relationship.

Yes, there is a client in [town name] whom is constantly a problematic client. He does not know how to run his business, where there is a business two blocks up the street who does three times the business he does just because of the way he chooses to run his business. I have had to give him ultimatums to get him to change his ordering habits. Basically what it boils down to is that if he wants to partake in any of our products or our specials he has to start changing his actions and gain some of our trust. (S3)

\subsubsection{Betrayal}

Betrayal seems to be one of the most important and easily justifiable reasons to end a relationship that is already characterized by low trust. At the same time, it appears that it is the most difficult one to articulate. Throughout the interviews, we observed that the informants preferred either short sentences and/or general terms (instead of describing particular incidents) when they talk about betrayal. They were unwilling to provide any details about the betrayal incidents. Later in the paper, we will provide more discussion about the implications of this observation.

Well at various times.....uh.....and I probably won't want to get into details....I have cut ties with some businesses I felt had betrayed me or something...I already wasn't feeling good about this one guy (referring his supplier) for a while and when I felt he betrayed me, I just went somewhere else. That's capitalism I guess, huh? (B15)

\subsubsection{Not caring and unfair/unreasonable business partner}

Our study indicates that caring and being reasonable are important factors that industrial buyers and suppliers expect from their business partners in order to maintain the relationship. These dimensions are like Renn and Levine (1991) and Kasperson, Golding, and Tuler (1992) who viewed fairness (acknowledgement and adequate 
representation of all relevant points of view) and caring (concern for and benefice to trusting individuals) as important attributes of trust. Further, Kumar et al. (1995) suggested that fairness plays an important role in developing long term relationships between relatively smaller, vulnerable resellers and larger, powerful suppliers.

Yeah. I had two competing companies, which I don't wish to mention their names, that were selling the same products. Both companies were offering the same product at basically the same price. I would take all the products from one company over the other company every time because I knew the one company already had a lot of business, whereas the other company didn't have as much business but they would give me more personal attention. So, every time I would take the products over the other company because I had a better relationship with the other company. Again, it goes back to that trust factor, I didn't trust the larger company, so I decided I would take every other product possible from the other company. The larger company just didn't seem to care about me or my business, where the other company did. (B27)

The same buyer indicated that he had to terminate some of his businesses because the suppliers were not reasonable. The buyer interpreted the supplying firm's policies and bureaucratic structure as being unreasonable and unfair. As mentioned above, when fairness of the partner is in question, the buyers seem to "take their business elsewhere."

We have a supplier for some hydraulic materials that we use for our concrete breaking machine, that we were supposed to get a one percent discount for if we pay in fifteen days. In working with our accounting department, there have been some circumstances that have arisen. The company was counting the invoice in the fifteen days, when it took five to six days for the materials to be shipped to us. Also, the supplier was counting weekends in the fifteen days, where most companies only count Monday through Friday. So basically, we were down to two or three days to pay this fifteen-day invoice for the discount. So we were constantly denied the discount because we could not meet their fifteen-day rule. So we asked them to change their policy, or we would take our business elsewhere. After I talked with the sales rep, he said there was nothing he could do. I said there was nothing else I could do but what's best for the company and take my business elsewhere. Another supplier out there, could supply the same materials under the same conditions, but was more lenient. I had a great relationship with this guy, but just because of the bureaucratic situation he's under, I had to take my business elsewhere. He needed to work something out to re-gain my trust, some kind of negotiation. (B27)

The idea of an unfair/unreasonable business partner is also evident in some of our buyer informants who end a high sales pressure relationship. This buyer, for example, indicated that his supplier lacked understanding, and expected him to place orders sooner. If the order is not placed quickly, then the supplier will begin to doubt the performance of the buyer.

Um, I have in the past, not while working here in this store, but yeah, there was this one T-shirt manufacturer in Kansas. He had a great product line, he had good stuff, he had good prices, but he was a high pressure-salesman. He couldn't understand why we weren't buying from him already, he was wondering what was wrong with us type of thing and I wouldn't buy from the guy if he paid me to. And then there are other people who offer kickbacks, and they didn't sit well with me so I never bought from them again. (B32)

\subsubsection{Not a profitable business}

Finally, the same buyer suggested that profitability is a driving force of the business. Therefore, when the business became unprofitable, he had to end some of his business relationship even when he "liked doing business with" that supplier.

...Especially if they couldn't deliver, and I've even had to do this with people I like doing business with. Their companies weren't delivering, they weren't making up on their promises, you know, ship dates were promised and they didn't come in; you've got to do what's right for business, so sometimes you have to sever those relationships. If it's not going to be profitable for me then I have to stop doing business with them. Also, if their prices get too high and it makes it not competitive, I can't buy from them anymore. (B32)

\section{Discussion}

The aim of this study was to provide some insight into the complex dynamics of ongoing inter-organizational relationships. Our specific interest was the concept of trust. Using qualitative research techniques, we attempted to provide an in-depth understanding of some of the understudied and/or unresolved issues. In their extensive review article, Seppanen et al. (2007) point out the importance of future research that investigates "the temporal element of trust in inter-organizational studies” (p. 261). Our paper responds to this call by identifying the changing nature of the level of trust as the buyer-supplier relationship matures. In our study, this change was found to be particularly visible for suppliers, but not for buyers. One of the important consequences of the temporal nature of trust is the emergence of "dark side" behaviors. Our study revealed a number of relational (or as we call them, "relationship stretching") dark side behaviors that may eventually harm an ongoing buyer-supplier relationship. Furthermore, our findings revealed that, even though over time, "the role of trusting individuals may diminish" (Seppanen et al., 2007, p. 261), the relationship may continue. Moreover, as suggested by a number of scholars in inter-organizational studies, qualitative inquiries such as ours, have the potential to lay the groundwork to better understand and measure the role and the dynamics of trust in organizational buyer-supplier relationships (e.g. Arnott, 2007; Bunduchi, 2008; Rousseau et al., 1998; Seppanen et al., 2007). We believe that our findings can offer, "implications on the development of suitable metrics [to study] temporal dynamics and level of analysis in inter-organizational trust" (Seppanen et al., 2007, p. 261). In this section, we discuss specific contributions of our study to interorganizational trust literature, make suggestions for future research, and list practical implications for marketing channels and sales management.

\subsection{Contributions to literature}

The buyer informants tend to treat both new and long term partners similarly. On the other hand, the suppliers make clear distinctions between their trust in short and long term partners. These findings have important implications for research on interorganizational trust. As evidenced through the interview excerpts, buyers have the same expectations of the new suppliers as they do of the long term suppliers. Suppliers, on the other hand, believe that trust is built and developed over time. In other words, our findings suggest that the fundamental ways of thinking about trust may differ between buyers and suppliers (also see Thomas \& Skinner, 2010). One implication of these findings is that pre-relational trust may figure prominently in supplier selection decisions, but make little or no sense to suppliers (Ekici \& Sohi, 2000; Marimuthu \& Dean, 2008). Additionally, studies based around buyer perceptions (e.g. Ganesan, 
1994) have not demonstrated a significant relationship between duration of a partnership and trust. Our findings suggest that the relationship between duration and trust may be more meaningful when we investigate trust from the supplier's point of view. More importantly, our findings suggest the need to approach buyers' and sellers' perceptions of trust separately.

Let us elaborate this last point further. As a part of our interviews, we asked all the respondents about their "interactions" with long term versus short term business partners. Both buyer and supplier informants indicated that their interactions with short term and long term partners are different; they reported more frequent and more personal interaction with long term partners as compared to short term partners (see Tables 2 and 3 for examples of interview excerpts).

Earlier, we suggested that buyers do not see differences in the trust they have for their long versus short term suppliers. However, they see their interactions as different between the two types of suppliers. These findings may suggest that, compared to suppliers, buyers tend to make clearer distinctions between personal interactions with suppliers and trust in suppliers. Similar to the "calculative economic reasoning" argument of Williamson (1993, p. 453), our findings further suggest that buyers appear to view trust more as an "economic exchange" construct. Suppliers make close connections between the

\section{Table 2}

Suppliers' interactions with short term versus long term partners ${ }^{\mathrm{a}}$.

S16: Oh yeah, that just goes back to the palin' around, or someone I've been talking to since I have stepped foot in there. It's just like calling up one of my friends from the house here and there is nothing weird involved in it. Uhh, yeah but did you say short time or first time?

Interviewer: Just relatively new clients.

S16: It's just all about rapport, it just takes time to get to know somebody. You can usually tell pretty quickly, if you're talking to someone that's not, just about anybody can tell that. If you're talking to someone that's nice or if you don't get along or not right off the bat. But yeah, the longer you're with them the longer you trust them.

S36. Yes, with long time clients, a lot of business is done over the phone. With new

clients, you have to see them face to face quite often in order for you to start a trusting relationship. You have to make it more personal.

S8: Exactly, I think that they are different in the beginning and that it starts mainly on a smaller scale, I can pretty much tell, this person is very nice, I think I can trust this person, this person is not going to you know lie to me a lot or I think that they are going to do what they say and I'm going to do what I say so that they have a trust in me, for instance, Latin America, I gotta go to Argentina to go to Chile in the next thirty days, I met a perspective new client at furniture show out in Highpoint, North Carolina, about a week ago, met these gentlemen who run a manufacturing plant, and they're great really nice people and I could feel that we were developing trust within the first fifteen minutes of the conversation and that there was a comfort level there for both parties and so I'm going to be flying down there and they want me to come and learn about them and so once we learn a little bit more about each other as people and then I'm going to learn a little bit more about their business and there's going to be a bit more interactions personally and so that we'll both gain some trust.

$\mathrm{S} 1$ :Yeah, more personal in the long run. I mean, after you get to trust someone, I mean

You get more personally involved. I mean you get to know their kids, their birthdays,

You know, just things like that, and that builds and then there's business issues, which

make it a little easier.

S14: Yeah, like I said it all go back to the friendship thing. I have a couple of accounts where I can go in and not bring up pitchbook or any type of point of sale and just say hey listen we got this going next week, wanna do it? Let's do it whereas the people you don't know quite as well they don't trust you as well either so you have to convince them this is the way to go, that this is what they should do. So it takes a lot more convincing on my end, but yeah it's a lot different. I mean, people I've been around a long time it's more like small talk.

a These excerpts represent a sample of responses to the question "Are the interactions between you and your long time clients different from the interactions between you and your relatively new clients?"

\section{Table 3}

Buyers' Interactions with short term versus long term partners ${ }^{\mathrm{a}}$.

B11: Uh, yeah, probably to some extent and that kinda goes to the personal relationship that you have built with the person you're in contact with. And, um, obviously it's going to be a little stronger bond with the people you've done business with over a longer period of time. But, then there are reps that you just connect with automatically. And you know, and so it may not take as long, you know to build more of a personal type relationship. But, um, I'm sure, you know, there's the different types.

B24: Yes they are. For example, I will sit down with Nate, like I said before, for fifteen minutes to a half of an hour weekly. And some of the newer suppliers, it's kind of how it was with him in the beginning. It's fairly touch and go. They come in and do what they need to do for me, but we don't really talk about anything else. Nate and I sit and talk about a lot of different things that are going on. Whether it be football or other restaurants down the streets or whatever.

B7: Russ: Yes, definitely. As you get on a more personal basis, you get to know more of their personal likes and dislikes and they get to know mine.

B36: When you deal with the same person for so long, you know that person. And it's almost like a friendship. But a friendship you maybe joke around a little bit, or...I don't know I guess, just a little bit different relationship there. Until you have dealt with that supplier for a while and come to understand how that suppliers thinks. And how each other thinks and operates and does business.

B8: Yes, with a long term supplier I will have not only a business relationship but also a personal relationship with them like I will go to dinner with them when they are in town or whatever. With a short term supplier I don't have those types of relationships with I generally not make myself available for social engagements with a short term supplier that I don't order from.

B30: I have a supplier, my nuts and bolts guy, comes in and I know him really well; I knew him before I started to work with X, from the Y (actual names were deleted). I could sit down with him and have both a comfortable business and personal conversation. You just can't do that with your new clients because that personal level has not been reached yet.

a These excerpts represent a sample of responses to the question "Are the interactions between you and your long time suppliers different from the interactions between you and your relatively new suppliers?"

level and quality of personal interactions with their short versus long term partners and their trust in these partners. These findings may suggest that suppliers view trust more as a "relational" construct than as a primarily economic exchange construct. Future studies may test the generalizability of our findings.

Recently, Yang et al. (2011) applied social embeddedness theory (i.e. the concept of strong versus weak tie relationships) to explain the role of trust and formal control on opportunism and long term orientation. The buyers in our study appeared to perceive their relationships with suppliers in the form of a "weak tie." As noted by Yang et al. (2011), "self-interest motivates profit-seeking behavior in weak tie situations, and cool and atomistic personal relationships characterize these relationships" (p. 89). As suggested earlier, the suppliers in our study, however, perceive their relationships with buyers in the form of a "strong tie." Yang et al. (2011) characterized strong tie relationships "by trust and personal connections that might go far beyond narrow economic transactions" (p. 89). Our findings, along with the arguments of Yang et al. (2011), may provide further support for the notion that buyers and suppliers view their relationships with (and their trust for) each other through completely different lenses (also see Handfield \& Bechtel, 2002; Thomas \& Skinner, 2010). As can be seen from Tables 2 and 3, supplier informants make clear connections between the level of interactions and trust, whereas buyer informants do not make clear indications about the relationship between interactions and their trust. These assertions may also be tested in future studies.

Behavioral consequences of trust are complex. Although it is appealing to argue that trusting relationships are beneficial for the exchange, our data indicates that there are many dark sides associated with these trusting relationships. Thus, we believe that the dark side behaviors reported in our analysis deserve further academic attention. Literature on betrayal suggests that it is highly possible that a partner's trust in the other party can be betrayed through 
opportunistic behaviors. Trust is a necessary precursor to group living and the development of specific relationships, and higher levels of trust are associated with greater likeability and happiness. On the other hand, the very process of trusting specific people increases the likelihood of being betrayed (Jones et al., 1991; Metts, 1989; Miller et al., 1986). Further, the persons most likely to betray are the closest friends and relations (e.g. Jones, Couch, \& Scott, 1997). We believe the integration of trust and betrayal efforts in the context of inter-organizational studies provides a unique opportunity to understand the complexity and dialectical nature of such relationships.

Our findings illustrate the following two general types of dark side behaviors: those that are related to "economic exchange," and those that are related to "relationship exchange." Economic exchangerelated dark side behaviors are discussed in the literature as "opportunistic" behaviors (e.g. Elangovan \& Shapiro, 1998; Grayson \& Ambler, 1999; Moorman et al., 1992). Rules that govern interorganizational relationships are not only a matter of economic exchange. In a broader social systems perspective, inter-organizational relations are subject to the same behavioral processes associated with all social systems (e.g. Stern \& Brown, 1969). However, to our knowledge, relationship exchange-related dark side behaviors (or as we call "relationship stretching" behaviors) have received limited scholarly attention. Two notable exceptions are Fang et al. (2011), who studied how relationship tensions can moderate the positive relationship between relationship quality and relationship functions, and Anderson and Jap (2005), who argued that strong interpersonal relationships between partners may lead to dark side behaviors.

Some research supports that "giving extras" is foundational in forming friendships and influences customer satisfaction (Price \& Arnould, 1999). In addition, the sales management literature provides a conceptual understanding for salespeople to "engage in discretionary efforts that enhance organizational outcomes" (Dubinsky \& Skinner, 2002, p: 589). However, through our study, we identified various relationship stretching dark side behaviors that can potentially harm business. The social norms of a trusting relationship bear similarities to norms for gift-giving, and future research may benefit from employing this metaphor to examine trust. In light of our findings, we suggest future research on the "relationship stretching" aspects of dark side behaviors. Such studies would provide valuable insight and expand the rather limited literature on relationship dissolution (Anderson \& Jap, 2005; Das, 2006).

Earlier in the paper, we talked about our observations regarding informant reactions to betrayal situations-they are basically unwilling to talk about it. Yet, the damages caused by betrayal are beyond sheer economic damages. There are personal harms associated with the betrayal type of dark side behavior. As Govier (1998) indicates in his article "Distrust and Its Discomforts," betrayal is the violation of a deep trust and confidence. "Betrayal is worse than unreliability or deception, worse than many acts of harm...A person betrayed is let down by another with whom he or she has experienced a special closeness, intimacy, and history of emotional connection" (p. 143-144). It is plausible to argue that a person who has been betrayed by his or her business partner, among other things, loses self confidence, and perhaps loses confidence in the industry in which he/she does business. Loss of confidence can potentially affect his or her operations at the micro level, and the economy at the macro level. Considering individual, dyadic, and macro level implications, we suggest future research for a deeper understanding of betrayal motives and consequences in inter-organizational relationships.

Fig. 2 should be viewed as the results that emerged from our data about the dynamic relationships between the level of trust and relationship specific outcomes. It appears that the termination of an ongoing (but low or no trust) relationship is less likely to be initiated by suppliers. The only reason mentioned by suppliers to end a low/no trust relationship is when they conclude that the buyer is an "incompetent business partner." At the same time, suppliers appear to have various motives to remain in a relationship where they think there is little or no trust. Buyers, on the other hand, have more variety of reasons to terminate a low/no-trust business relationship. They also have various motives to sustain the relationship, even when they don't trust the supplier. The threshold for terminating a low/no-trust relationship seems lower for buyers than suppliers. In light of these results, we believe that more research on conditions where trust doesn't matter may complement our far greater understanding of where it does.

A further look at the industry profiles provided by the informants indicates that almost all of the suppliers operate in an "intensely competitive" environment. Only one company (a beer distributor) indicated that they were a monopoly in the market and therefore, they did not worry about competition. This is interesting because the data indicates that the main reason buyers terminate their relationship with a not-trusted supplier is the availability of the alternatives. In many cases, due to the lack of alternatives and therefore high level of dependence, buyers would prefer to continue doing business with these not-trusted suppliers. Yet, almost all suppliers believe that their markets have intense competition. This might suggest that buyers and sellers have different perceptions about the "intensity of competition" in their markets, and their recourse to alternatives. Considering the inherit limitations of our study, we believe that future research that focuses on the perceptions of dependence would also make a valuable contribution to the literature on power and dependence in the same marketplace, as well as to the moderating role of competitive intensity on the relationship between buyer-supplier trust (Zhao \& Cavusgil, 2006).

In the last section of our analysis, we suggested that exchange partners may be willing to terminate their nontrusting relationship in the presence of alternative "places to go." In other words, we identified categories and themes based on the assumption that there are alternatives for exchange partners to pursue. It is plausible to argue that today's business-to-business environment offers more alternatives to firms than at any other time in the history of the industrial era. Electronic and information technologies (IT), and especially electronic commerce via the Internet, have opened countless gates to both buyers and suppliers. In such business environments, retaining long term business relationships through establishing and nurturing trust appears to be imperative (Bunduchi, 2008; Lancastre \& Lages, 2006). We reported in the findings that there are certain attributes of trust (such as being reasonable, caring, flexible, and fair) that, if not provided, can lead to the termination of relationships. Due to the challenges associated with maintaining long term relationships in the e-commerce era (Wilson \& Abel, 2002), we suggest further research to investigate the role of these attributes on trust and relationship termination.

\subsection{Managerial implications}

In addition to its contributions to inter-organizational trust literature, our study offers a number of managerial insights. In this section, we briefly list our major findings and discuss their implications for marketing channels and sales management.

1. The results suggest that the relationship between duration of the business relationship and trust for the other party can be more meaningful from the supplier point of view. In other words, while buyers tend to treat both new and long term partners similarly, suppliers tend to make clear distinctions between their trust in short and long term partners. It appears from the buyers' perspective that a certain and sufficient level of trust does exist before the actual business relationship with the supplier begins. These results, although they may not apply to all industries, suggest that buyers in an organization may be readily ready to trust a potential supplier without a direct and performance-related 
experience. That is, buyers may be more interested in the performance potential of a new supplier and/or its sales associates. Since (for buyers) trust is a "kind of instant connection," the first-time impression the buyer gets from the sales representatives becomes extremely crucial.

2. Results suggest that even though buyers may not see differences in the trust they have for their long versus short term suppliers, they see their interactions as different between the two types of suppliers. Further, regardless of duration of the relationship, buyers appear to view trust as an "economic exchange" construct, while supplier view trust as a "relational" construct. In other words, for buyers, interactions with suppliers must result in visible economic gains to be meaningful. Based on these findings, we suggest that when designing customer relationship management (CRM) activities and/or loyalty programs, suppliers should take into consideration that their channel partners (i.e. clients) are more likely to be motivated when such CRM activities lead to visible economic gains. A successful example of such activities is the Eggympic (the Egg Olympics). Eggympic ("Yumurpiyat" in Turkish) is organized every other year by the Turkish branch of Throw Nutrition International, the Dutch animal feed and supplycompany. The organization brings together suppliers and buyers of poultry industry in Turkey. The 3-day event which takes place in a luxurious resort hotel in the Mediterranean coast of Turkey includes seminars, panel discussions, as well as various sports and cultural activities performed by all the participants in teams. These activities create a bond among companies that represent vertical and horizontal dimensions of this particular supply chain. The interactions during the event lead to specific implicit and explicit "economic gains" for buyers, including a free all-inclusive vacation with the family, opportunity to meet industry-specific bureaucrats and engage in lobbying activities, take advantage of attractive event-specific promotions offered by suppliers, and engage in business-related cooperative activities with other buyers.

3. Results further suggest that there are many dark-sides associated with trusting relationships. Companies put their trust in the hands of exchange partners, hoping to receive greater positive relational outcomes (satisfaction, performance, commitment, etc.). However, it is also possible to argue that trusting relationships established by companies increase the likelihood and potential damage of being betrayed by the company's trusted partners. From the practical point of view, it becomes crucial to monitor the dark side intentions of channel partners. Arguably, one of the most effective ways to suppress or prevent dark side consequences of close relationships is to, "evaluate older relationships" (Anderson \& Jap, 2005, p. 79). In this paper, we offer a framework to monitor an ongoing relationship, both for buyers and suppliers. More specifically, we provide a list of "expectations" that may come from an exchange partner, and signal a dark side motive. Continuous evaluation of exchange partners based on their "relationship stretching expectations" may prevent future dark side behaviors, and their harmful consequences for the business.

4. We identified two types of dark-side behavior: economic exchangerelated and relational exchange-related. Practical implications of economic exchange related dark side has been recognized and discussed among scholars and practitioners. The relational exchange-related dark side behavior (or as we call them "relationship stretching") may also have important implications for sales management. It appears, based on the findings, that there is a crucial tension between reciprocating trust (extending extras), and at the same time, not taking advantage of a trusted exchange partner. Each partner is expected to give the other partner "a break," but neither partner is supposed to ask for or expect "a break." Such asymmetry in expectations can become an important source of sales person-client conflict and can lead to the termination of otherwise a smoothly-operating business relationship. As a result, these findings suggest that, for both buyers and suppliers, expectation management becomes as important as the other components of trust (e.g. fairness, caring, offering good price, making payments on time, creating positive word-of-mouth) for healthy, long term and prosperous business relationships.

5. Our results suggest that low/no trust relationships may not necessarily lead to relationship termination. However, the results further indicate that termination of an ongoing (but low or no trust) relationship is less likely to be initiated by suppliers. Buyers, on the other hand, have more variety of reasons to terminate a low/no trust business relationship. These findings provide systematic and empirical evidence to the common belief that "it is usually more advantageous to retain a customer than to gain one." At the same time, we believe that relationship termination motives and behaviors, of both buyers and suppliers, are crucial for practitioners. Both buyers and suppliers provide self-, other-, relationship-, and industry-specific reasons for continuing low/ no-trust relationships. Moreover, both buyers and suppliers hold the other party responsible for conflicts that lead to the break-up, rather than questioning themselves or their trustworthiness in the relationship. From the practical point of view, these findings support the notion that developing a sense of empathy for the other party is critical for an effective channel conflict resolution.

\section{Conclusion}

This study provides an in-depth understanding of some of the understudied and/or unresolved issues of inter-organizational trust. The paper proposes a model that delineates the relationships between levels of trust (high-low) and their potential behavioral consequences (continuation/termination), for buyers as well as for suppliers. This inductive model suggests that ongoing relationships that are characterized by trust may also breed "dark side" intentions and behaviors. The paper proposes a unique set of dark side (i.e. relationship stretching) behaviors that may eventually reduce an exchange partners' trust in the other party. Low levels of trust, in turn, may or may not lead to relationship termination, depending on certain industry, buyer, supplier, and relationship characteristics. Therefore, by providing a detailed account for the potential moderating factors influencing the future of a relationship (i.e. the "motives" in Fig. 2), this paper makes an important contribution to the rather limited literature on relationship dissolution.

The qualitative nature of our study has both its advantages (as discussed earlier) and limitations. Fig. 2 depicts the emerging model/framework of our study. Testing the applicability of our framework in broader empirical settings as well as the generalizability of the conclusions drawn in the previous section call for future research. Moreover, even though we interviewed more than 70 buyers and suppliers in diverse industries, it may be unwise to generalize the applicability of the results to all types of organizational buyer-supplier relationships. Most of the buyers and suppliers we interviewed represented small to mid-size companies. The institutional and individual characteristics of trust, as well as the diffusion of trust within an organization, may differ in smaller and in larger organizations. The manner in which temporal elements and dynamics of trust play out in large inter-organization relationships calls for future research. Such research may initially employ qualitative techniques to lay out a grounded framework, and then go on to measure (test) the emerging models of inter-organizational trust in broader empirical settings. 
Appendix A. Supplier profiles ${ }^{a}$.

\begin{tabular}{|c|c|c|c|c|c|c|c|c|}
\hline $\mathrm{S}$ & Age & Sex & Job title & Duration. of contact w/buyer & Freq. of cont. w/buyer & Industry & Other & Goods/service \\
\hline 1 & $56-65$ & $\mathrm{~F}$ & S. Rep & $1 \mathrm{~h}$ & Once a week & Food dist & State owned/both small and big companies & G \\
\hline 2 & $25-35$ & $\mathrm{M}$ & S. Rep & $45-90 \mathrm{~min}$ & Every 2 weeks & Agri/chemical & Intense competition/ever changing/mergers & G \\
\hline 3 & $25-35$ & M & S. Rep & Varies & Varies & Drink & Largest company in the market & G \\
\hline 4 & $25-35$ & $\mathrm{M}$ & S. Rep & Regular & Regular bases & Advertising & Competitive & $\mathrm{S}$ \\
\hline 5 & $36-45$ & $\mathrm{M}$ & S. Rep & $4-45 \min$ & Once a month & Drink & Intense competition & GS \\
\hline 6 & $46-55$ & M & Owner & $30-60 \mathrm{~min}$ & Once a week & Office supplies & Competitive market & G \\
\hline 7 & $25-35$ & M & S. Mang. & $30 \mathrm{~min}-2 \mathrm{~h}$ & Every 2 weeks & Agri/chemical & Intense competition & G \\
\hline 8 & $46-55$ & $\mathrm{~F}$ & S. Mang. & 1-3 days & Twice a year & Furniture & Intense competition/relationship buying & G \\
\hline 9 & $25-35$ & M & Mark. Assoc. & $30-60 \mathrm{~min}$ & Once a month & Drink & Intense competition/strict regulations & GS \\
\hline 10 & $25-35$ & M & S. Mang. & $30 \mathrm{~min}$ & Once a week & Drink & Intense competition/strict laws & G \\
\hline 11 & $25-35$ & $\mathrm{~F}$ & S. Rep & NA & NA & Telemarketing & Internet: big competitor & $\mathrm{S}$ \\
\hline 12 & $25-35$ & $\mathrm{~F}$ & Acc. Exec. & $30-60 \mathrm{~min}$ & 2 a month & Telecomm. & Competitive & GS \\
\hline 13 & $25-35$ & $\mathrm{~F}$ & S. Rep & $30-60 \mathrm{~min}$ & NA & Pharmaceutical & Competitive & G \\
\hline 14 & $36-45$ & M & S. Rep & $30 \mathrm{~min}$ & $12-18$ a year & Hardware & Very competitive/relationships important & G \\
\hline 15 & $36-45$ & $\mathrm{M}$ & S. Rep & $1-2 \mathrm{~h}$ & Once a week & Food dist & Timing is important & G \\
\hline 16 & $25-35$ & $\mathrm{M}$ & S. Rep & $15-30 \mathrm{~min}$ & 2-4 a week & Agri/chemical & Very relationships/relationships important & G \\
\hline 17 & $25-35$ & M & S. Assoc. & $15-30 \mathrm{~min}$ & $2-4$ a month & Pharmaceutical & High competition & G \\
\hline 18 & $25-35$ & M & S. Assoc. & $1-2 \mathrm{~h}$ & Varies & Agri/construc & Competitive/relationship based & G \\
\hline 19 & $36-45$ & M & S. Rep & $5 \mathrm{~min}$ & 30-60 a year & Food dist & Intense competition & G \\
\hline 20 & $36-45$ & $\mathrm{M}$ & Exec VP & $20-60 \mathrm{~min}$ & Once a week & Drink & Only Bud distributor in town & GS \\
\hline 21 & $36-45$ & $\mathrm{M}$ & S. Mang. & $10-45 \mathrm{~min}$ & Every 2 weeks & Drink & No competition & GS \\
\hline 22 & $25-35$ & $\mathrm{M}$ & Acc. Mang. & $20 \mathrm{~min}$ & Once a week & Drink & Very competitive & GS \\
\hline 23 & $25-35$ & M & S. Rep & $1-30 \mathrm{~min}$ & Every 6 weeks & Pharmaceutical & Tight Competition/regulations & $\mathrm{G}$ \\
\hline 24 & $36-45$ & $\mathrm{M}$ & VP Sales & $10-45 \min$ & $2-4$ a month & Food dist & Tight competition/risks are high & GS \\
\hline 25 & $25-35$ & M & S. Mang. & $10 \mathrm{~min}$ & 2-3 a week & Auto parts & Internet: growing competitor & G \\
\hline 26 & $36-45$ & $\mathrm{~F}$ & S. Counselor & $10-40 \mathrm{~min}$ & Once a week & Food dist & Competitive/15 companies in the market & GS \\
\hline 27 & $36-45$ & M & Acc. Salesperson & $45-60 \mathrm{~min}$ & Twice a year & Agri/chemical & Somewhat competition/not many big names & GS \\
\hline 28 & $46-55$ & $\mathrm{M}$ & S. Rep & $5-60 \mathrm{~min}$ & Once a month & Construction & Very competitive/relationships important & G \\
\hline 29 & $\mathrm{~N} / \mathrm{A}$ & NA & NA & NA & NA & NA & $\mathrm{NA}$ & NA \\
\hline 30 & $25-35$ & M & S. Rep & $2-30 \mathrm{~min}$ & $2-4$ a week & Drink & A few large companies/regulations & G \\
\hline 31 & $36-45$ & M & Real Estate & Varies & Every 2 month & Real estate & Competitive & GS \\
\hline 32 & $56-65$ & $\mathrm{M}$ & S. Mang. & $45-60 \mathrm{~min}$ & 5 times a year & Textbook & Internet: new competitor & G \\
\hline 33 & $\mathrm{~N} / \mathrm{A}$ & M & Co-owner & $50 \mathrm{~min}$ & NA & Agri/Construc & Large investment needed & GS \\
\hline 34 & $\mathrm{~N} / \mathrm{A}$ & NA & NA & NA & NA & NA & NA & NA \\
\hline 35 & $36-45$ & M & Mang. & $5-15 \min$ & Once a week & Repair/service & Timing is important & GS \\
\hline 36 & $36-45$ & $\mathrm{M}$ & S. Rep & $30 \mathrm{~min}$ & Twice a month & Photography & Competition & GS \\
\hline
\end{tabular}

\footnotetext{
${ }^{a}$ NA is used for the respondents who did not want some or any of their profile information to be reported.
}

Appendix B. Buyer profiles ${ }^{a}$.

\begin{tabular}{|c|c|c|c|c|c|c|c|c|}
\hline B & Age & Sex & Job title & $\begin{array}{l}\text { Duration. of cont. } \\
\text { w/supplier }\end{array}$ & $\begin{array}{l}\text { Freq. of cont. } \\
\text { w/supplier }\end{array}$ & Industry/business & Other & Goods/service \\
\hline 1 & $25-35$ & $\mathrm{~F}$ & GM & $10 \mathrm{~min}-2 \mathrm{~h}$ & $2-3$ a year & Bookstore & Risky inventory management & G \\
\hline 2 & $25-35$ & M & Territory M & $5-90 \min$ & Once a week & Agri/chemical & Competitive & GS \\
\hline 3 & $36-45$ & M & Store M. & $30 \mathrm{~min}$ & 1-2 a day & Grocery retail & Timely delivery important & G \\
\hline 4 & $25-35$ & M & VP aviation & Varies & Often & Aviation & Competitive & GS \\
\hline 5 & $36-45$ & $\mathrm{~F}$ & Owner/M. & Varies & Varies & Food/restaurant & Big competition & $\mathrm{S}$ \\
\hline 6 & $25-35$ & $\mathrm{~F}$ & VP operations & $30-60 \mathrm{~min}$ & Once a week & Banking & Mergers & $\mathrm{S}$ \\
\hline 7 & $25-35$ & M & Farmer & $60-90 \mathrm{~min}$ & Once a week & Agri/chemical & Changing industry & G \\
\hline 8 & $36-45$ & $\mathrm{~F}$ & GM & $1-4 \mathrm{~h}$ & Once a month & Furnishings & Competitive/relationships & G \\
\hline 9 & $46-55$ & M & Manager & Varies & Varies & Drink/bar & Large size-muscled suppliers & $\mathrm{S}$ \\
\hline 10 & $25-35$ & M & GM & $30 \mathrm{~min}$ & 1-2 a week & Food/restaurant & Prefers long relationships & $\mathrm{S}$ \\
\hline 11 & $25-35$ & M & Purchaser & Varies & Varies & Telecom & Volatile environment & $S$ \\
\hline 12 & $25-35$ & M & Owner/M. & $15 \min$ & Once a month & Tree \& landscape & Seasonal work & $\mathrm{S}$ \\
\hline 13 & $25-35$ & $\mathrm{~F}$ & Med. assist. & $30 \mathrm{~min}$ & 2 a month & Medicine & Very pushy and competitive & $S$ \\
\hline 14 & $46-55$ & M & Project M. & Varies & Varies & NA & Not much personal interactions, mostly business & $\mathrm{S}$ \\
\hline 15 & $36-45$ & M & Owner/M. & $1-2 \mathrm{~h}$ & Once a week & Food/restaurant & Timing is important & $\mathrm{S}$ \\
\hline 16 & $46-55$ & M & Farmer & $15-30 \mathrm{~min}$ & 2-4 a week & Agri/chemical & Changing environment/regulations & G \\
\hline 17 & $25-35$ & $\mathrm{~F}$ & Pharmacist & $20-30 \mathrm{~min}$ & 2 a month & Pharmaceutical & Strong competition/highly regulated & GS \\
\hline 18 & $46-55$ & M & Owner/M. & $1 \mathrm{~h}$ & Varies & Welding & Lack of many quality supplier & GS \\
\hline 19 & $46-55$ & $\mathrm{~F}$ & Coordinator & $5-30 \mathrm{~min}$ & 3-4 a week & Food/restaurant & Government business/university policies & $\mathrm{S}$ \\
\hline 20 & $25-35$ & M & Owner/M. & $20-60 \mathrm{~min}$ & Once a week & Drink/bar/rest. & Highly regulated & $\mathrm{S}$ \\
\hline 21 & $36-45$ & M & GM & $15 \mathrm{~min}$ & $2-3$ a month & Food/restaurant & Competitive & $\mathrm{S}$ \\
\hline 22 & $25-35$ & M & Co-owner & Varies & Varies & Drink/bar/rest. & Competition high & $\mathrm{S}$ \\
\hline 23 & $36-45$ & $\mathrm{~F}$ & Physician & $10 \mathrm{~s}-1 \mathrm{~h}$ & Varies & Medicine & Somewhat competition/regulations & S \\
\hline 24 & $46-55$ & M & Owner/M. & $15-30 \mathrm{~min}$ & 3 a week & Food/restaurant & Fierce competition & $\mathrm{S}$ \\
\hline 25 & $46-55$ & M & $\mathrm{VP} / \mathrm{M}$ & $10 \mathrm{~min}-3 \mathrm{~h}$ & 3-4 a week & Auto parts & Very competitive & GS \\
\hline
\end{tabular}


Appendix B (continued)

\begin{tabular}{|c|c|c|c|c|c|c|c|c|}
\hline B & Age & Sex & Job title & $\begin{array}{l}\text { Duration. of cont. } \\
\text { w/supplier }\end{array}$ & $\begin{array}{l}\text { Freq. of cont. } \\
\text { w/supplier }\end{array}$ & Industry/business & Other & Goods/service \\
\hline 26 & $36-45$ & $\mathrm{~F}$ & Owner/M. & $2 \mathrm{~h}$ & 4 a week & Food/restaurant & Highly competitive & $\mathrm{S}$ \\
\hline 27 & $25-35$ & M & Purchaser & Varies & Daily & Industrial equipment & Big suppliers dominates & G \\
\hline 28 & $46-55$ & M & Owner/M. & $1 \mathrm{~h}$ & Once a week & Construction & Relationships are important & $\mathrm{S}$ \\
\hline 29 & $\mathrm{~N} / \mathrm{A}$ & NA & NA & NA & NA & NA & NA & NA \\
\hline 30 & $25-35$ & M & Owner/M. & $2-30 \mathrm{~min}$ & 2-4 a week & Drink/bar/rest. & Regulated market and competitive & $\mathrm{S}$ \\
\hline 31 & $36-45$ & M & Estate $\mathrm{Br}$. & Varies & Varies & Real estate & Down market & $S$ \\
\hline 32 & $36-45$ & M & Store M. & $15 \min$ & 1 every 2 week & Textbook/bookstore & Customers shop online more often & G \\
\hline 33 & $25-35$ & M & Self empl. & NA & NA & NA & NA & \\
\hline 34 & $\mathrm{~N} / \mathrm{A}$ & NA & NA & NA & NA & NA & NA & NA \\
\hline 35 & $25-35$ & $\mathrm{M}$ & Purch. M. & $15 \mathrm{~min}$ & Daily & Grocery/retail & Competitive & $\mathrm{S}$ \\
\hline 36 & $36-45$ & M & Owner/M. & $5-30 \mathrm{~min}$ & 1-2 a week & Photography Shop & Competitive & $\mathrm{S}$ \\
\hline
\end{tabular}

a NA is used for the respondents who did not want some or any of their profile information to be reported.

\section{References}

Alderson, W. (1958). Marketing behavior and executive action. Homewood, Illinois: Richard D. Irwin.

Alderson, W. (1965). Dynamic marketing behavior. Homewood, Illinois: Richard D. Irwin.

Andaleeb, S. S. (1996). An experimental investigation of satisfaction and commitment in marketing channels: The role of trust and dependence. Journal of Retailing, 72, 77-93.

Anderson, E., \& Jap, S. D. (2005). The dark side of close relationships. MIT Sloan Management Review, 46, 75-82.

Anderson, J. C., \& Narus, J. A. (1990). A model of the distributor's perspective of distributor-manufacturer working relationships. The Journal of Marketing, 48, 62-74.

Anderson, E., \& Weitz, B. A. (1989). Determinants of continuity in conventional industrial channel dyads. Marketing Science, 8, 310-323.

Argyris, C. (1952). The impact of budgets on people. New York: Controllership Foundation.

Arnott, D. C. (2007). Trust-current thinking and future research. European Journal of Marketing, 41, 981-987.

Astley, W. G. (1985). Administrative science on socially constructed truth. Administrative Science Ouarterly, 30, 497-513.

Axelrod, R. (1984). The evolution of cooperation. New York: Basic Books.

Barber, B. (1983). The logic and limits of trust. New Brunswick, NJ: Rutgers University Press.

Barney, J. B., \& Hansen, M. H. (1994). Trustworthiness as a source of competitive advantage. Strategic Management Journal, 15, 175-216.

Baxter, L. A. (1985). Accomplishing relationship disengagement. In S. Duck, \& D. Perlmand (Eds.), Understanding personal relationships (pp. 243-265). Beverly Hills, CA: Sage Publications, Inc.

Bies, R. J., \& Tripp, T. M. (1996). Beyond distrust: 'Getting even' and the need for revenge. In R. Kramer, \& T. Tyler (Eds.), Trust in organizations: Frontiers of theory and research.. Thousand Oaks, CA: Sage.

Blau, P. M. (1964). Exchange and power in social life. New York: Wiley.

Bowlby, J. (1982). Attachment and loss, volume 1: Attachment. New York: Basic Books.

Bromiley, P., \& Cummings, L. L. (1995). Transaction cost in organizations with trust. Research on Negotiation in Organizations, 5, 219-247.

Bunduchi, R. (2008). Trust, power and transaction costs in B2B exchanges-A socio-economic approach. Industrial Marketing Management, 37, 610-622.

Casson, M. (1990). Enterprise and competitiveness: A systems view of international business. Oxford: Clarendon Press.

Charmaz, K. (1983). The grounded theory method: An explication and interpretation. In R. M. Emerson (Ed.), Contemporary field research: A collection of readings.. Boston: Little Brown.

Chiles, T. H., \& McMackin, J. F. (1996). Integration variable risk preference, trust, and transaction cost economics. Academy of Management Review, 21, 73-99.

Cox, T. (1991). The multicultural organization. The Executive, 5, 34-37.

Daft, R. L. (1983). Learning the craft of organizational research. Academy of Management Review, 8, 539-546

Dahlstrom, R., \& Nygaard, A. (1995). An explanatory investigation of interpersonal trust in new and mature markets. Journal of Retailing, 71, 339-361.

Das, T. K. (2006). Strategic alliance temporalities and partner opportunism. British Journal of Management, 17, 1-21.

Das, T. K., \& Teng, B. (1998). Resource and risk management in the strategic alliance making process. Journal of Management, 24, 21-42.

Dasgupta, P. (1998). Trust as a commodity. In D. Gambetta (Ed.), Trust: Making and breaking cooperative relations (pp. 49-72). New York: Basil Blackwell.

Doney, P. M., \& Cannon, J. P. (1997). An examination of the nature of trust in buyerseller relationships. The Journal of Marketing, 61, 35-51.

Doney, P. M., Cannon, J. P., \& Mullen, M. R. (1998). Understanding the influence of national culture on the development of trust. Academy of Management Review, 23, 601-620.

Dubinsky, A. J., \& Skinner, S. J. (2002). Going the extra mile: Antecedents of salespeople's discretionary effort. Industrial Marketing Management, 31, 589-598.

Duck, S. W. (1982). A topography of relationship disengagement and dissolution. In S. Duck, \& R. Gilmor (Eds.), Personal relationships, 4: Dissolving personal relationships. New York: Academic Press, Inc.

Dwyer, F. R., Schurr, P. H., \& Oh, S. (1987). Developing buyer-seller relations. The Journal of Marketing, 51, 11-28.
Ekici, A., \& Sohi, R. (2000). The role of pre-relational trust in first time supplier selection. In J. P. Workman, \& W. D. Perreault (Eds.), Marketing theory and applications (pp. 265-274). Chicago, IL: American Marketing Association.

Elangovan, A. R., \& Shapiro, D. L. (1998). Betrayal of trust in organizations. Academy of Management Review, 23, 547-566.

Fang, S. R., Chang, Y. S., \& Peng, Y. C. (2011). Dark side of relationships: A tension-based view. Industrial Marketing Management, 40, 744-784.

Finch, J., Wagner, B., \& Hynes, N. (2010). Trust and forms of capital in business-to-business activities and relationships. Industrial Marketing Management, 39, 1019-1027.

Ganesan, S. (1994). Determinants of long-term orientation in buyer seller relationship. The Journal of Marketing, 58, 1-19.

Ghosal, S., \& Bartlett, C. A. (1990). The multinational as an interorganizational network. Academy of Management Review, 15, 603-625.

Glaser, B., \& Strauss, A. (1967). The discovery of grounded theory: Strategies for qualitative research. New York: Aldine de Grayter.

Govier, T. (1998). Dilemmas of trust. Montreal, Ontario: McGill-Queen's University Press.

Granovetter, M. S. (1985). Economic action and social structure: The problem of embeddedness. The American Journal of Sociology, 91, 481-510.

Grayson, K., \& Ambler, T. (1999). The dark side of long-term relationships in marketing services. Journal of Marketing Research, 36, 132-141.

Greenberg, J. (1997). The STEAL motive: Managing the social determinants of employee theft. In R. Giacalone, \& J. Greenberg (Eds.), Antisocial behavior in organizations. Thousand Oaks, CA: Sage.

Hakansson, H. (1982). International marketing and purchasing of industrial goods by the IMP Group. Chichester: John Wiley.

Hakansson, H., \& Snehota, I. (1995). Developing relationships in business networks. London: Routledge.

Handfield, R. B., \& Bechtel, C. (2002). The role of trust and relationship structure in improving supply chain responsiveness. Industrial Marketing Management, 31, 367-382.

Held, V. (1968). On the meaning of trust. Ethics, 78, 156-159.

Hill, C. (1990). Cooperation, opportunism, and the invisible hand: Implications for transaction cost theory. Academy of Management Review, 15, 500-513.

Hogan, R., \& Hogan, J. (1994). The mask of integrity. In T. Sarbin, R. Carney, \& C. Eoyang (Eds.), Citizen espionage: Studies in trust and betrayal (pp. 107-125). Westport, CT: Praeger.

Huemer, L., Bostrom, G. O., \& Felzensztein, C. (2009). Control-trust interplays and the influence paradox: A comparative study of MNC-subsidiary relationships. Industrial Marketing Management, 38, 520-528.

Jones, W. H., Cohn, M. G., \& Miller, C. E. (1991). Betrayal among children and adults. In K. J. Rotenberg (Ed.), Children's interpersonal trust.. New York: Springer-Verlag.

Jones, W. H., Couch, L., \& Scott, S. (1997). Trust and betrayal: The psychology of getting along and getting ahead. In R. Hogan, J. Johnson, \& S. Briggs (Eds.), Handbook of personality psychology.. San Diego: Academic Press.

Kasperson, R. E., Golding, D., \& Tuler, S. (1992). Sitting hazardous facilities and communicating risk under conditions of high distrust. Journal of Social Issues, 48, 161-187.

Knorr-Cetina, K. (1981). The manufacturing of knowledge: An essay on the constructivis and contextual nature of science. New York: Pergamon Press.

Kumar, N., Scheer, L. K., \& Steenkamp, J. (1995). The effects of supplier fairness on vulnerable resellers. Journal of Marketing Research, 32, 348-356.

Lancastre, A., \& Lages, L. F. (2006). The relationship between buyer and a B2B e-marketplace: Cooperation determinants in an electronic market context. Industrial Marketing Management, 35, 774-789.

Latour, B. (1982). Science in action. Cambridge, MA: Harvard University Press.

Leonidou, L., Talias, M. A., \& Leonidou, C. N. (2008). Exercised power as a driver of trust and commitment in cross-border industrial buyer-seller relationships. Industrial Marketing Management, 37, 92-103.

Lewicki, R. J. (1983). Lying and deception: A behavioral model. In M. Bazerman, \& R. J. Lewicki (Eds.), Negotiating in organizations.. Beverly Hills, CA: Sage.

Lewicki, R. J., \& Bunker, B. B. (1995). Developing and maintaining trust in work relationships. In R. M. Kramer, \& T. R. Tyler (Eds.), Trust in organizations: Frontiers of theory and research (pp. 114-139). Thousand Oaks, CA: Sage.

Lincoln, Y. S., \& Guba, E. G. (1985). Naturalistic Inquiry. Thousands Oaks, CA: Sage.

Liu, Y., Yuan, L., Tao, L., \& Wang, Y. (2008). Relationship stability, trust, and relational risk in marketing channels: Evidence from China. Industrial Marketing Management, 37 432-446. 
Locke, K., \& Golden-Biddle, K. (1997). Constructing opportunities for contribution: Structuring intertextual coherence and 'problematizing' in organizational studies. Academy of Management Journal, 40, 1023-1062.

Lofland, J., \& Lofland, L. H. (1995). Analyzing social settings: A guide to qualitative observation and analysis (3rd ed.). Belmont, CA: Wadsworth Publishing Company.

Lohtia, R., Bello, D. C., \& Porter, C. E. (2009). Building trust in US-Japanese business relationships: Mediating role of cultural sensitivity. Industrial Marketing Management, 38, 239-252.

Marimuthu, M., \& Dean, A. M. (2008). Developing pre-relational trust in technology service providers. In T. Kautonen, \& H. Karjaluoto (Eds.), Trust and new technologies: Marketing and management on the Internet and mobile media (pp. 227-243).

Mayer, R. C., Davis, J. H., \& Schoorman, F. D. (1995). An integrative model of organizational trust. Academy of Management Review, 20, 209-222.

McAllister, D. J. (1995). Affect- and cognition-based trust as foundations for interpersonal cooperation in organization. Academy of Management Journal, 38, 24-59.

McGary, E. G. (1952). The contractual function in marketing. Journal of Business, 96-113 (April).

McKnight, D. H., Cummings, L. L., \& Chervany, N. L. (1998). Initial trust formation in new organizational relationships. Academy of Management Review, 23, 473-490.

Metts, S. (1989). An exploratory investigation of deception in close relationship. Journal of Social and Personal Relationships, 6, 159-179.

Miles, M. B. (1984). Qualitative data analysis: A source book of new methods. Beverly Hills, CA: Sage.

Miles, M. B., \& Huberman, M. (1994). Qualitative data analysis: An expanded sourcebook (2nd ed.). Thousands Oaks, CA: Sage.

Miller, G. R., Mongeau, P. A., \& Sleight, C. (1986). Fudging with friends and lying to lovers: Deceptive communication in personal relationships. Journal of Social and Personal Relationships, 3, 495-512.

Miller, G., \& Parks, M. (1982). Communication in dissolving relationships. In S. W. Duck (Ed.), Personal relationships, 4: Dissolving personal relationships.. New York: Academic Press, Inc.

Moorman, C., Zaltman, G., \& Deshpande, R. (1992). Relationships between provider and users of market research: The dynamics of trust within and between organizations. Journal of Marketing Research, 29, 314-329.

Morgan, R. M., \& Hunt, S. D. (1994). The commitment-trust theory of relationship marketing. The Journal of Marketing, 58, 20-38.

Nametz, P. L., \& Christensen, S. L. (1996). The challenge of cultural diversity: Harnessing a diversity of views to understand multiculturalism. Academy of Management Journal, $21,434-462$.

Oliver, C. (1990). Determinants of interorganizational relationships: Integration and future directions. Academy of Management Review, 15, 241-265.

Pratt, M. G., \& Rafaeli, A. (1997). Organizational dress as a symbol of multilayered social identities. Academy of Management Journal, 40, 862-898.

Price, L. L., \& Arnould, E. J. (1999). Commercial friendship: Service provider-client relationships in context. The Journal of Marketing, 63, 38-56.

Rafaeli, A., Dutton, J., Harquail, C. V., \& Mackie-Lewis, S. (1997). Navigating by attire: The use of dress by female administrative employees. Academy of Management Journal, 40, 9-45.

Rempel, J. R., Holmes, J. G., \& Zanna, M. P. (1985). Trust in close relationships. Journal of Personality and Social Psychology, 49, 95-112.

Renn, O., \& Levine, D. (1991). Credibility and trust in risk communication. In R. E. Kasperson, \& P. M. Stallen (Eds.), Communicating risk to the public: International perspectives.. Amsterdam: Kluwer.

Rotter, J. B. (1967). A new scale for the measurement of interpersonal trust. Journal of Personality, 35, 651-665.

Rousseau, D. M., Sitkin, S. B., Burt, R. S., \& Camerer, C. (1998). Not so different after all: A cross-discipline view of trust. Academy of Management Review, 23, 393-404.

Ryu, S., Min, S., \& Zushi, N. (2008). The moderating role of trust in manufacturer-supplier relationships. The Journal of Business and Industrial Marketing, 23, 48-58.

Sandberg, J. (2000). Understanding human competence at work: An interpretative approach. Academy of Management Journal, 43, 9-25.
Seabright, M. A., Levinthal, D. A., \& Fichman, M. (1992). Role of individual attachments in the dissolution of interorganizational relationships. Academy of Management Journal, $35,122-160$

Selnes, F., \& Sallis, J. (2003). Promoting relationship learning. The Journal of Marketing, 67, 80-95.

Seppanen, R., Blomqvist, K., \& Sundqvist, S. (2007). Measuring inter-organizational trust-A critical review of the empirical research in 1990-2003. Industrial Marketing Management, 36, 249-265.

Shapiro, S. P. (1987). The social control of impersonal trust. The American Journal of Sociology, 93, 623-658.

Sheth, J. N., \& Parvatiyar, A. (1994). Relationship marketing: Theory, methods, and application-1994 Research Conference Proceedings. Emory University, Atlanta: Center of Relationship Marketing.

Sitkin, S. B., \& Roth, N. L. (1993). Explaining the limited effectiveness of logistic 'remedies' for trust/distrust. Organization Science, 4, 367-392.

Smith, J. B., \& Barclay, D. W. (1997). The effectiveness of organizational differences and trust on the effectiveness of selling partner relationships. The Journal of Marketing, $61,3-21$

Stern, L. W., \& Brown, J. W. (1969). Distribution channels: A social systems approach. In L. W. Stern (Ed.), Distribution channels: Behavioral dimensions (pp. 6-19). New York, NY: Houghton Mifflin.

Strauss, A., \& Corbin, J. (1990). Basics of qualitative research: Grounded theory. Newbury Park, CA: Sage.

Suh, T., \& Houston, M. B. (2010). Distinguishing supplier reputation from trust in buyer-seller relationships. Industrial Marketing Management, 39, 744-751.

Thomas, R., \& Skinner, L. (2010). Total trust and trust asymmetry: Does trust need to be equally distributed in interfirm relationships? Journal of Relationship Marketing, 9, 43-53.

Wallendorf, M., \& Belk, R. W. (1989). Assessing trustworthiness in naturalistic consumer research. In E. C. Hirschman (Ed.), SV-Interpretive consumer research (pp. 69-84). Provo, UT: Association for Consumer Research.

Wang, S., \& Huff, L. C. (2007). Explaining buyers' responses to sellers' violation of trust. European Journal of Marketing, 41, 1033-1052.

Weick, K. E. (1989). Theory construction as disciplined imagination. Academy of Management Review, 14, 516-531.

Wicks, A. C., Berman, S. L., \& Jones, T. M. (1999). The structure of optimal trust: Moral and strategic implications. Academy of Management Review, 24, 99-116.

Williamson, O. E. (1993). Calculativeness, trust, and economic organizations. Journal of Law and Economics, 36, 435-486.

Wilson, S. G., \& Abel, I. (2002). So you want to get involved in E-commerce. Industrial Marketing Management, 31, 85-94.

Yang, Z., Zhou, C., \& Jiang, L. (2011). When do formal control and trust matter? A context-based analysis of the effects on marketing channel relationships in China. Industrial Marketing Management, 40, 86-96.

Zand, D. E. (1972). Trust and managerial problem solving. Administrative Science Quarterly, 17, 229-239.

Zhao, Y., \& Cavusgil, S. T. (2006). The effect of supplier's market orientation on manufacturer's trust. Industrial Marketing Management, 35, 405-414.

Zucker, L. G. (1986). Production of trust: Institutional sources of economic structure, 1840-1920. Research in Organizational Behavior, 8, 53-111.

Zuckerman, H. (1988). The sociology of science. In N. J. Smelser (Ed.), Handbook of sociology (pp. 511-574). Newbury Park, CA: Sage.

Ahmet Ekici is an Assistant Professor in Faculty of Business Administration, Bilkent University, Ankara, Turkey. His research interests include relationship marketing (trust in both consumer and organizational contexts), macromarketing (quality of life, consumer well-being, developing markets, poverty, and ethics) and public policy (food safety, institutional trust, vulnerable groups, and poverty). His research has appeared in journals such as Journal of Macromarketing, Journal of Public Policy and Marketing, Journal of Business Research, Journal of Business Ethics, Industrial Marketing Management, Journal of Research for Consumers and Social Indicators Research. 